NBER WORKING PAPER SERIES

\author{
THE RISE AND FALL OF MONEY \\ GROWTH TARGETS AS GUIDELINES \\ FOR U.S. MONETARY POLICY
}

Benjamin M. Friedman

Working Paper 5465
NATIONAL BUREAU OF ECONOMIC RESEARCH
1050 Massachusetts Avenue
Cambridge, MA 02138
February 1996

This paper was prepared for the Bank of Japan conference, "Towand a More Effective Monetary Policy," Tokyo, October 26-27, 1995. I am grateful to Jeff Amato for research assistance, to Stephen Cecchetti, Kenneth Kuttner, David Longworth, Gregory Mankiw, William Poole, Jordan Rappaport, George Rich and James Stock for helpful discussions and comments on an earlier draft, to Donald Kohn and Richard Porter for their cooperation in providing data, and to the G.E. Foundation and the Harvard Program for Financial Research for research support. This paper is part of NBER's research program in Monetary Economics. Any opinions expressed are those of the author and not those of the National Bureau of Economic Research.

(c) 1996 by Benjamin M. Friedman. All rights reserved. Short sections of text, not to exceed two paragraphs, may be quoted without explicit permission provided that full credit, including $\odot$ notice, is given to the source. 


\title{
THE RISE AND FALL OF MONEY GROWTH TARGETS AS GUIDELINES \\ FOR U.S. MONETARY POLICY
}

\begin{abstract}
A familiar question raised by the Federal Reserve System's evolving use of money growth targets over the past twenty years is whether monetary policymakers had sound economic reasons for changing their procedures as they did -- either in adopting money growth targets in the first place, or in subsequently abandoning them, or in both instances. This paper addresses that question by comparing two kinds of evidence based on U.S. time-series data: first, evidence bearing on what Federal Reserve policymakers should have known about the relationship of money to income and prices, and when they should have known it; and second, evidence showing how and when the Federal Reserve changed its actual (as opposed to stated) reliance on money growth targets. The main conclusion from this comparison is that whatever economic conditions might have warranted reliance on money growth targets in the 1970s and early 1980s had long disappeared by the 1990 s, so that abandoning these targets was an appropriate response to changing circumstances. Whether adopting money growth targets earlier on was likewise appropriate is less clear.
\end{abstract}

\author{
Benjamin M. Friedman \\ Department of Economics \\ Littauer Center 127 \\ Harvard University \\ Cambridge, MA 02138 \\ and NBER
}


Revised

January, 1996

THE RISE AND FALL OF MONEY GROWTH TARGETS

AS GUIDELINES FOR U.S. MONETARY POLICY

Benjamin M. Friedman*

Harvard University

The practice of central banking seems always to be changing, and the role of money growth targets as guidelines for monetary policy is as good an example as any. With remarkable rapidity - at least in retrospect - quantity targets based on specified monetary aggregates assumed center stage in the conduct of monetary policy, only then to move to the periphery or even fade from the scene altogether. This same evolution, and with about the same timing, has occurred in one central bank after another around the world.

In 1970, the central banks of most of the world's major industrialized economies were carrying out monetary policy primarily in terms of interest rates and/or quantitative credit restrictions. By 1980 the use of money growth targets was an idea whose time had come. Most of the major central banks had put such targets at the core of their monetary policymaking process. By 1990 money growth targets were mostly a thing of the past. Today most central banks have either de-emphasized their monetary aggregate targets or dropped them altogether, in some cases returning to interest rate-based policy procedures and in others seeking out new organizing principles like direct inflation targets. Today only the Deutsche Bundesbank continues to pledge firm allegiance to money growth targets (and, the Bundesbank's rhetorical claims notwithstanding, German 
monetary growth has actually fallen within the designated target range only once in the four years since 1990).

The evolution of monetary policymaking in the United States has followed this pattern as well. The Federal Reserve System began to experiment with explicit money growth targets in 1970. Beginning in 1975, Congress required the Federal Reserve to establish money growth targets and publicly announce them in advance. In 1979 the Federal Reserve publicly declared an intensified dedication to controlling money growth and implemented new day-to-day operating procedures designed to enhance its ability to do so. In 1987 the Federal Reserve gave up setting a target for the narrow money stock but continued to set targets for broader measures of money. In 1993 the Federal Reserve publicly acknowledged that it had "downgraded" even its broad money growth targets -. a change that most observers of U.S. monetary policy had already noticed long before.

The question most obviously raised by this about-and-about face is whether monetary policymakers had sound economic reasons for changing their procedures as they did - - either in first adopting money growth targets or in subsequently abandoning them, or in both instances. The object of this paper is to address this question from the perspective of U.S. monetary policy in particular. To anticipate, the paper's main conclusion is that whatever economic conditions might have warranted reliance on money growth targets in the 1970s and early 1980s had long disappeared by the 1990s, so that the Federal Reserve's "downgrading" of these targets was indeed an appropriate response to changing circumstances. Whether adopting money growth targets in the first place was likewise appropriate is less clear.

Section I briefly reviews what it means to make monetary policy with a money growth target and under what conditions doing so is useful. Section II 
presents evidence, based on U.S. time-series data, bearing on what Federal Reserve policymakers should have known about the relationship of money to income and prices, and when they should have known it. Section III presents evidence showing how the Federal Reserve changed its actual reliance on money growth targets over time. Section IV addresses the central question of whether the Federal Reserve acted sensibly in this regard, by evaluating the changes in policymaking documented in Section III in light of the changes in economic behavior documented in Section II. Section $V$ offers concluding observations. 
I. Some Familiar Basics ${ }^{1}$

The use of a money growth target conceptually transforms the making of monetary policy into a two-stage procedure, and in practice many central banks have implemented the monetary target strategy in just that way. In the first stage, policymakers determine the rate of money growth (however defined) that would be consistent with achieving their objectives for prices, real activity and whatever other goals they may seek to achieve, given their expectations about money demand, bank behavior, and any other factors that might influence the relevant relationships. In the second stage, the central bank implements policy actions - typically by setting either a short-term interest rate or the quantity of bank reserves -. so as to come as close as possible to making actual money growth track the corresponding target. In effect, the central bank acts, once the money growth target has been set, as if controlling money itself were the objective of monetary policy.

If the world presented no surprises - if developments never occurred that policymakers had not foreseen in the first stage of this process - - then acting at the second stage as if money growth were the policy objective would be indistinguishable from simply varying the interest rate or reserves directly so as to bring prices, real activity and other desiderata into line with policymakers' objectives and ignoring money altogether. But of course surprises do occur. Basing monetary policy on a money growth target provides a coherent way of taking the consequences of those unexpected developments into account. The opportunity to do so arises because central bank actions and their economic effects are separated both by time and by behavioral process: A change in the interest rate or the quantity of reserves makes a difference for economic activity later on. And the economic behavior that gives rise to that difference involves actions along the way that are, at least in principle, observable. 
Money growth -- again, in principle - - is just such an observable element of that intermediate behavior standing between central bank actions and their ultimate economic effects. Given that the central bank's main form of monetary policy action in a fractional reserve banking system is the purchase or sale of securities in exchange for bank reserves, most familiar models of the behavioral process connecting monetary policy to economic activity plausibly provide at least a potential role for fluctuations in some measure of money to anticipate movements in prices and/or real output. In the most conventional models, open market purchases provide reserves that enable banks to create more deposits, thereby reducing interest rates (as long as the demand for deposits is negatively interest elastic) and thus stimulating spending. A closely related alternative focuses on the importance of bank lending in financing either business or household expenditures, so that movements in money anticipate spending primarily because they reflect what is happening on the other side of the banking system's balance sheet. Yet a different view focuses initially on the presumed link between money and prices, with any effects on real activity arising as a consequence of the output decisions of producers unsure of how to interpret the limited information they receive as prices change.

In each of these models, however, the behavior that ultimately generates changes in prices and/or real activity also involves movements of money. To the extent that these movements in money occur not just logically but chronologically before the corresponding movements in prices and/or output, therefore, the central bank can take advantage of them to make changes from the initial setting of its interest rate or reserves instrument. Strictly defined, the use of a money growth target means that the central bank not only treats all unexpected fluctuations in money as informative in just this sense but also, as a quantitative matter, changes the interest rate or reserves in such a way as to 
offset these unexpected fluctuations altogether (or to the maximum extent possible) and thereby restore money growth to the originally designated target rate.

Alternatively, the central bank could incorporate money growth into its monetary policymaking process in a more flexible way, recognizing that movements in money are not always a sign of movements in prices and output to come. Faster money growth than expected might instead mean that the nonbank public is simply choosing to hold larger deposits in place of other forms of wealth, for reasons unrelated to spending or production decisions. Or it could mean that banks have decided that a smaller cushion of excess reserves is appropriate to newly prevailing market conditions. In using observed fluctuations in money growth to help guide monetary policy, therefore, policymakers may make judgments on a case by case basis in order to decide whether, and if so by how much, to change the interest rate or reserves when money growth behaves unexpectedly. Doing so amounts to using money growth not as a target but as an information variable. Although the central banks that have made money growth the focal point of their conduct of monetary policy have usually described their procedures in terms of money growth "targets," what most of them have actually done (including the Bundesbank) has usually amounted to using money growth as an information variable.

Regardless of whether the central bank makes money growth a target or uses it as an information variable, however, the whole concept is senseless unless observed fluctuations in money do anticipate movements of prices, or output, or whatever constitutes the ultimate objective of monetary policy: What would it mean to exploit an information variable that contains no relevant information? What would be the point in pursuing an intermediate target that is not observably intermediate between the central bank's actions and the intended 
consequences? In either case, whether movements in money anticipate movements in prices and/or output is crucial. That issue, in turn, is an empirical question. 
II. What Did They Know, and When Did They Know It?

The Federal Open Market Committee first included a money growth objective in its formal policy directive in February 1970, and money growth appears to have played an on-again off-again role in steering Federal Reserve actions over the next several years. ${ }^{2}$ The main story of the use of money growth targets as guidelines for U.S. monetary policy, however, begins a half decade later. In 1975 Congress adopted Joint Resolution 133 requiring the Federal Reserve System to announce in advance quantitative targets for the growth of key money (and credit) aggregates and, after the fact, to report to the relevant Congressional oversight committees on its success or failure in meeting these targets. The Open Market Committee's first published money growth targets specified desired growth rates for the $M 1, M 2$ and $M 3$ aggregates - - in each case expressed as a target range, rather than a point value -- for the one-year period from March 1975 to March 1976.

Narrow Money. Although the Federal Reserve set targets for the growth of three different monetary aggregates, the center of attention was clearly the narrow money stock M1, which then consisted essentially of currency and demand deposits. The theory of the demand for money for transactions purposes seemed well worked out, especially in comparison to the more open-ended issues involved in demand for money as a means of wealth holding, and as a practical matter it was straight forward that currency and demand deposits were then the two main ways of effecting transactions in the United States. (By contrast, endless debate and ambiguity surrounded any attempt to draw a line separating what was "money" from what wasn't for portfolio purposes.) Although Friedman and Schwartz's (1963) historical work had used a broader aggregate also including savings deposits at commercial banks (but not thrifts), by the time of Resolution 133 Goldfeld (1973) and others had pointed to $M 1$ as the measure of 
money exhibiting greatest stability in relation to income in the United States during the post World War II period. When the Federal Reserve dramatically adopted new operating procedures aimed at achieving targeted rates of money growth, in October 1979, once again M1 was the main focus of attention. Just what did the evidence of the mid to late 1970s show about the relationship of $M 1$ to either prices or output? And how has the evidence changed since then?

Figure 1 addresses these questions by showing, for each of a series of 101 different sample periods, the contribution of money to subsequent movements in real output (top panel) and prices (bottom panel) as estimated via the standard vector autoregression methodology. For each of the 101 samples, the figure indicates the respective percentages of output and prices accounted for by money at a two-year horizon. Each such percentage plotted is the product of a variance decomposition based on an underlying three-variable vector autorgression including real gross domestic product, the corresponding price deflator and the Ml money stock (all in logarithms and all seasonally adjusted), with four lags on each variable. The orthogonalization of this system for purposes of the variance decomposition places output first, prices second and money third. In each panel the solid line plots the estimated contribution of money to either output or prices, while the pair of dashed lines indicate the one-standard-error band of uncertainty associated with this estimate.

The initial percentage plotted in each panel of Figure 1 refers to the variance decomposition based on the three-variable vector autoregression estimated using quarterly data beginning in 1959:I and ending in 1974:IV. (Because of the four lags on each variable, the regression's first observation is $1960:$ I and so this initial sample includes 60 observations.) The two initial percentages plotted therefore indicate how someone applying this methodology in 
EIGURE 1

\section{PERCENTAGES OF QUTPUT AND RRICE YARIATION ACCOUNTED BOR BY MI AT A THO-YTAR BORTZON EOR 101 SAMPLES}

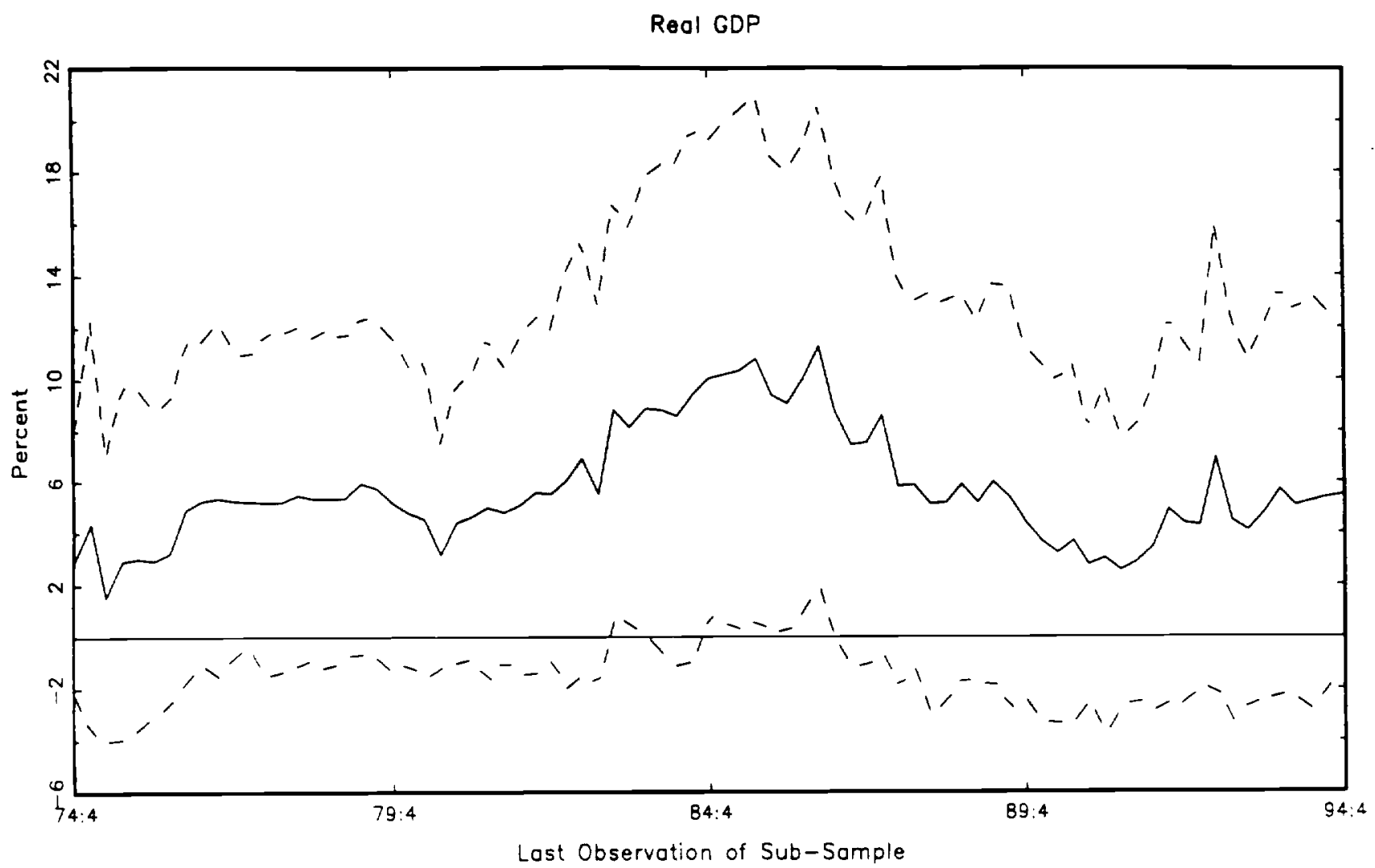

GDP Deflator

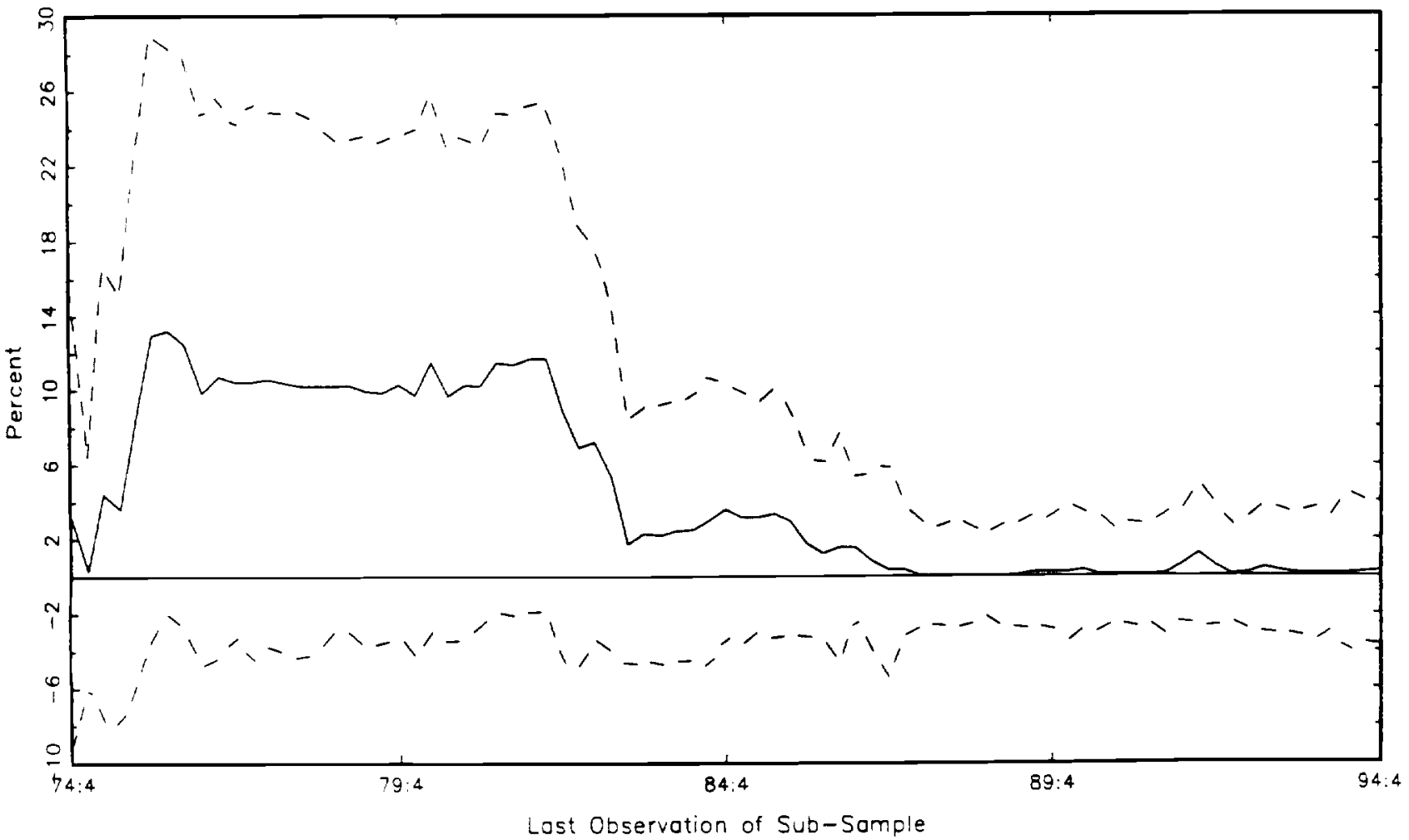


early 1975 would have assessed the contribution of the M1 money stock to predicting that part of the subsequent fluctuation of output and prices that is not already predictable from the prior fluctuation of output and prices themselves. ${ }^{3}$

The answer - again, as of 1975 -. is that knowing the recent movements of M1 contributes very little to predicting output and prices. At the two-year-ahead horizon considered in Figure 1, money accounts for not even 38 of the subsequent variation of output, and just over 38 of the variation of prices. Neither percentage is significantly different from zero, even at the weak standard reflected by the one-standard-error bands.

The other 100 points plotted in each panel of Figure 1 indicate the results of analogous variance decompositions based on sample periods ending in 1975:I, 1975:II, and so on through 1994:IV. In each case the question at issue is the same - how much M1 contributes to predicting that part of the subsequent fluctuation of output and prices not already predictable from output and prices themselves -- but the vantage point in time from which the question is asked continually moves forward. As the sample end date advances from 1974:IV to 1979:IV, the initial observation remains 1960:I so that the sample size expands (one observation at a time) from 60 to 80 quarters. Thereafter the end date and the beginning date both advance together, so that the sample size remains 80 quarters.

Matters changed somewhat as the end-of-sample vantage point advanced from 1975 to 1995 . The contribution of M1 to explaining subsequent output fluctuations remained small until the early 1980s, then increased for somewhat more than half a decade (and briefly even became statistically significant), then declined until 1990, and since then has modestly recovered but has remained insignificant. The contribution of $M 1$ to explaining subsequent price 
fluctuations increased rapidly after 1974, only to decline equally rapidly after 1981, and has since became negligible. It has remained statistically insignificant throughout.

Perhaps even more so than their variation over time, however, what is striking about the percentages plotted in both panels of Figure 1 is how small they are. At the peak, as seen from the vantage point of late 1986, Ml accounts for just over 118 of subsequent output fluctuations. The peak contribution for prices, seen from mid 1976, is just over 138. Moreover, it is not the case that these percentages are so small because two years is too long a time horizon over which to measure the predictive content of money. Appendix Figure A-I shows the results of analogous one-year-ahead varlance decompositions, based on the same vector autoregressions underlying Figure 1 . The results at a one-year horizon follow roughly similar ups and downs as in the two-year results, but especially for prices the percentage of variance accounted for by money is even smaller. An alternative way of addressing the contribution of money to predicting the subsequent variation of output or prices is to test explicitly the hypothesis that money has no such predictive power at all. In principle, the 101 vector autoregressions underlying the variance decompositions reported in Figure 1 readily admit such a test. Because each of the three variables in these regressions - - the respective (log) levels of output, prices and money -. is nonstationary, however, standard test statistics based on the normal distribution would be inappropriate for these regressions. Moreover, the distributions of the appropriate test statistics are known only for certain special cases. ${ }^{4}$

The two panels of Figure 2 therefore plot $p$-values for tests of the null hypothesis that all coefficients $\delta_{i}$ are zero in the two differenced equations 
EIGURE 2

SIGNIFICANCE OF UI IN RREDICTING OUTPUT AND PRICES ROR 101 SAYPLES

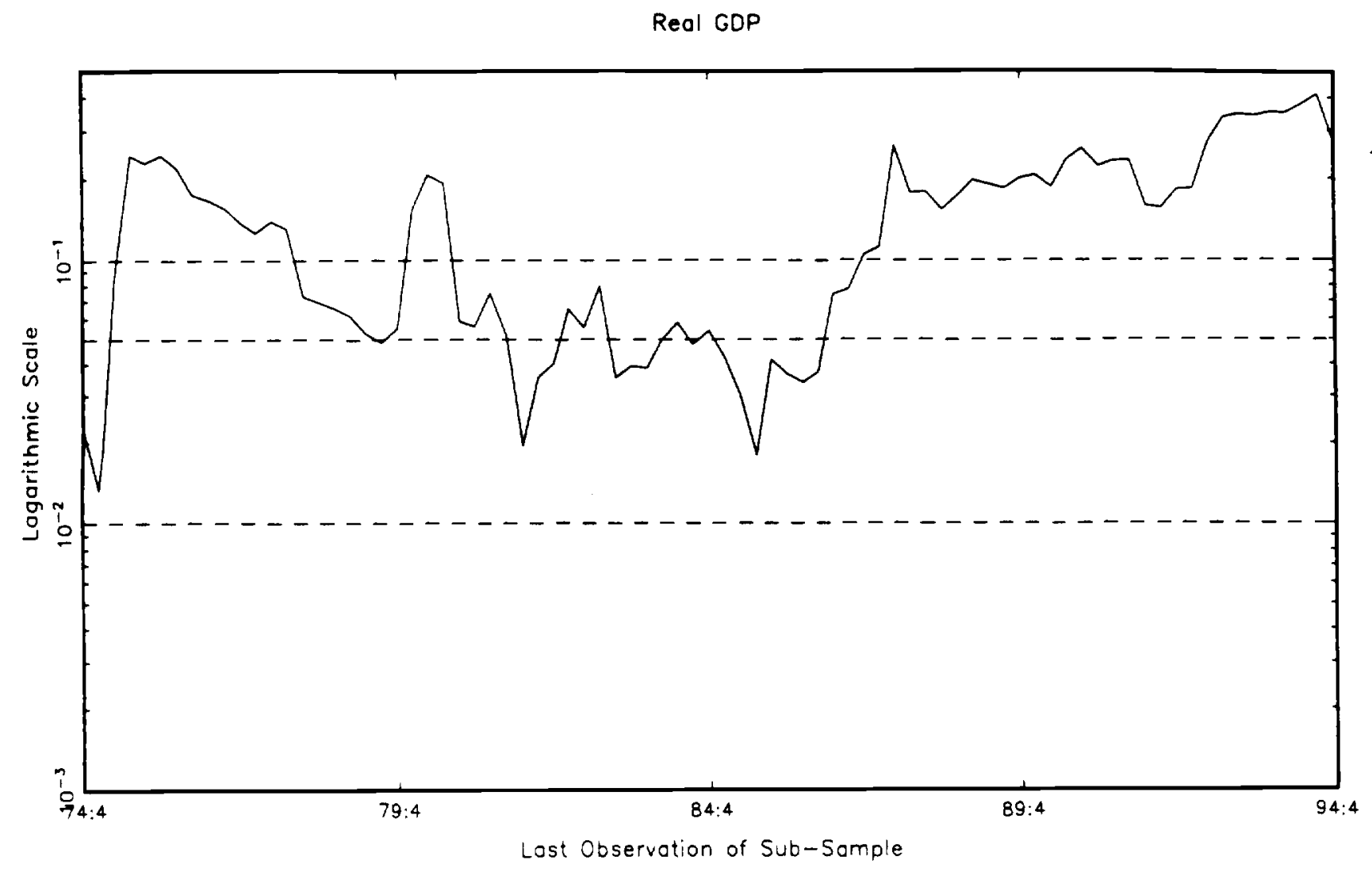

GDP Deflotor

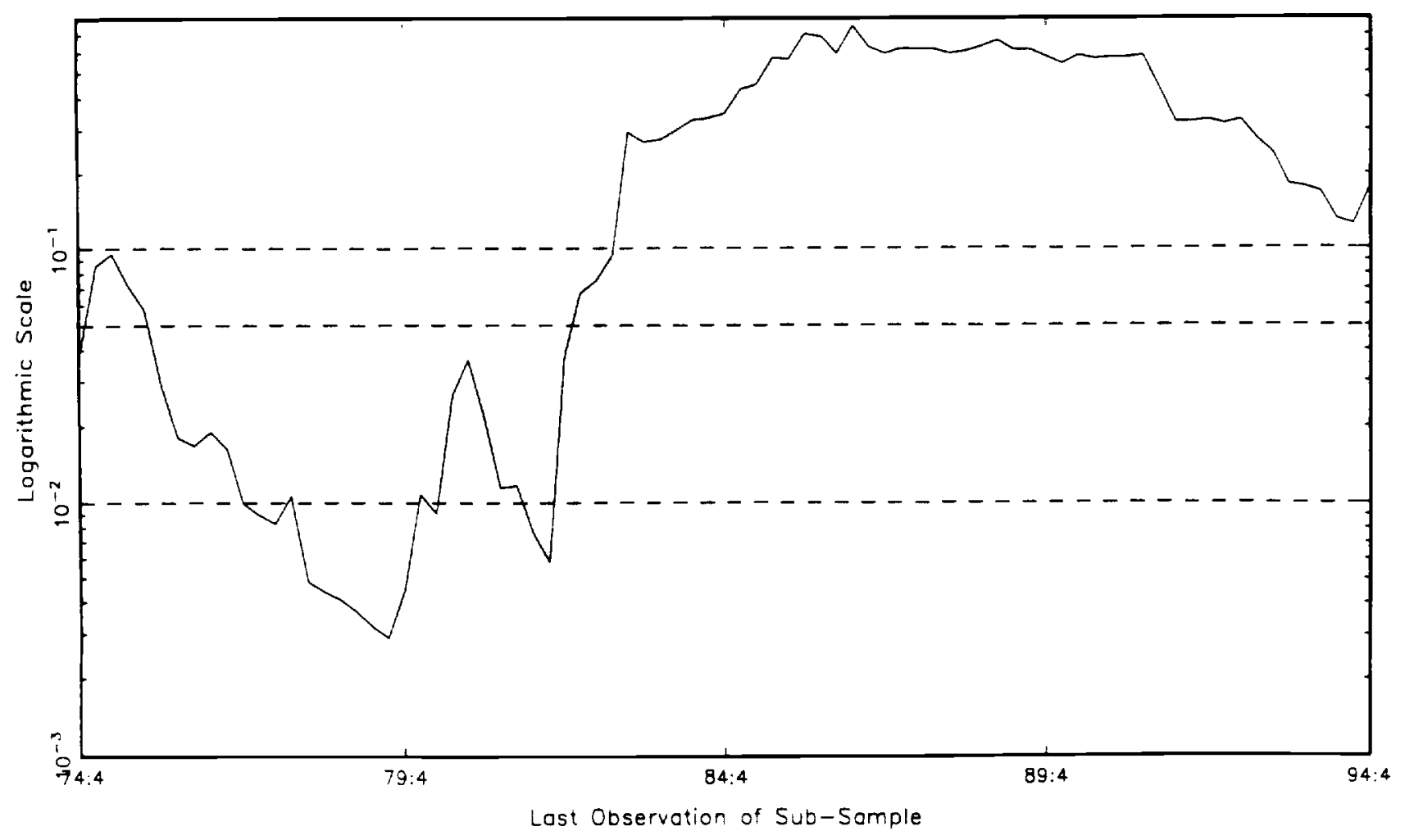




$$
\begin{aligned}
& \Delta x_{t}=\alpha+\sum_{i=1}^{4} \beta_{i} \Delta x_{t-i}+\sum_{i=1}^{4} \gamma_{i} \Delta p_{t-i}+\sum_{i=1}^{4} \delta_{i} \Delta m_{t-i}+u_{t} \\
& \Delta p_{t}=\alpha+\sum_{i=1}^{4} \beta_{i} \Delta x_{t-i}+\sum_{i=1}^{4} \gamma_{i} \Delta p_{t-i}+\sum_{i=1}^{4} \delta_{i} \Delta m_{t-i}+u_{t}
\end{aligned}
$$

where $x, p$ and $m$ are, respectively, the logarithms of real gross domestic product, the price deflator and the M1 money stock, $u$ is a disturbance term, and $\alpha$ and the $\beta_{i}, \gamma_{i}$, and $\delta_{i}$ are all coefficients to be estimated. In parallel with Figure 1, the first $p$-value plotted in each panel of Figure 2 gives the result of testing the null hypothesis of zero predictive content of money over the sample ending in 1974:IV, and the subsequent 100 values refer to the samples ending in 1975:I, 1975:II, and so on through 1994:IV. The dashed horizontal lines in each panel indicate the $.01, .05$ and .10 levels.

The results generated by this more explicit hypothesis test differ conceptually from the variance decomposition results shown in Figure 1 for several reasons. Most basically, asking the yes-no question of whether money has any predictive content with respect to output or prices is not the same as asking how much predictive content money has. In addition, the significance test based on the regression coefficients refers (by construction) to one-quarter-ahead prediction, while the variance decompositions reported above refer to a four-quarter horizon. Finally, levels are not the same as growth rates (although it is impossible to evaluate the force of this distinction because of the nonstationarity problem).

Given all of these differences of method, the p-values shown in Figures 2 do correspond at least approximately to the variance decomposition results in Figure 1, although the significance levels indicated in Figure 2 are clearly more generous. Judged from a vantage point any time between 1978 and 1987, M1 
has predictive content with respect to output that is significant at the .10 level, and for vantage points between 1981 and 1987 this predictive content is even significant at the .05 level. From any vantage point after 1987, however, there is no evidence of any predictive content event at the .10 level. Money has significant predictive content with respect to prices when judged from any vantage point through early 1983. During most of this early period, this predictive content is significant at the .05 level, and for brief periods it is significant at the .01 level. From any vantage point since 1983, however, there is no evidence of predictive content with respect to prices even at the .10 level.

As is well known, whether a vector autoregression implies that any particular variable has predictive content with respect to any other, and what variance decompositions ensue from the corresponding coefficient values, can change dramatically when the set of additional variables included in the regression system changes. More specifically in the context of this discussion, Sims (1980) showed that when an interest rate variable was added to a regression system analogous to that used above, and in which money did have predictive content with respect to output, then the interest rate had predictive content with respect to output but money did not. ${ }^{5}$ Because central banks are hardly unaware of interest rate movements, it is therefore useful also to evaluate the kinds of evidence presented in Figures 1 and 2 generated by a regression system that includes an interest rate along with output, prices and money.

Figure 3 presents series of two-year-ahead variance decomposition results that are analogous to those shown in Figure 1 in every way except that the underlying vector autoregression system includes the level of the federal funds rate as a fourth variable. (Appendix Table A-2 shows the corresponding one-year-ahead results.) Although the time paths traced out as the vantage 
EIGURE $\underline{3}$

PERCENTAGES OF OUTPUT AND PRICE VARIATION ACCOUNTED FOR BY M1

AT A TUO-YFAR HORIZON EQR 101 SAYPLES (SYSTEY ALSO INCLUDES FEDERAL FUNDS RATE)

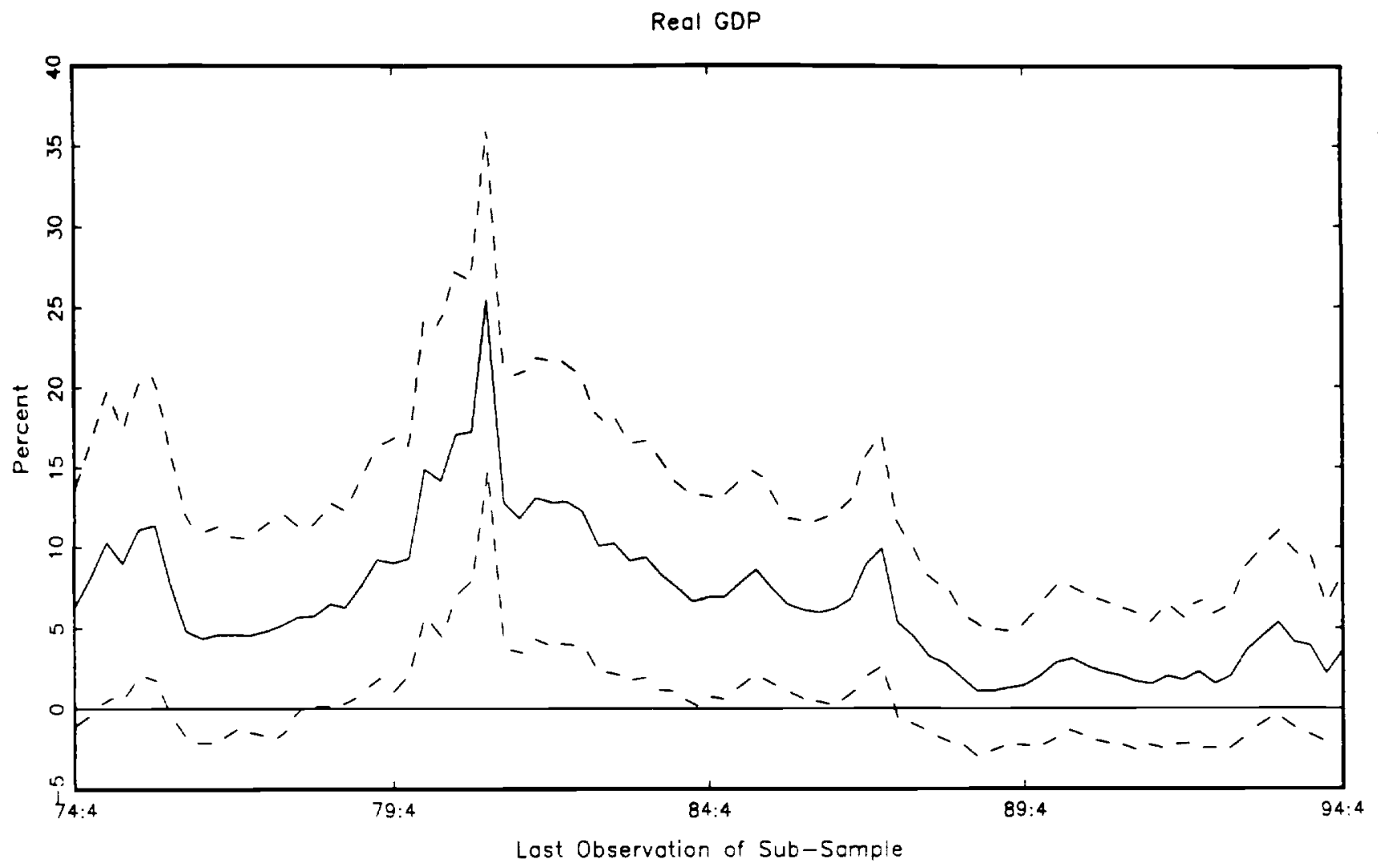

GDP Deflator

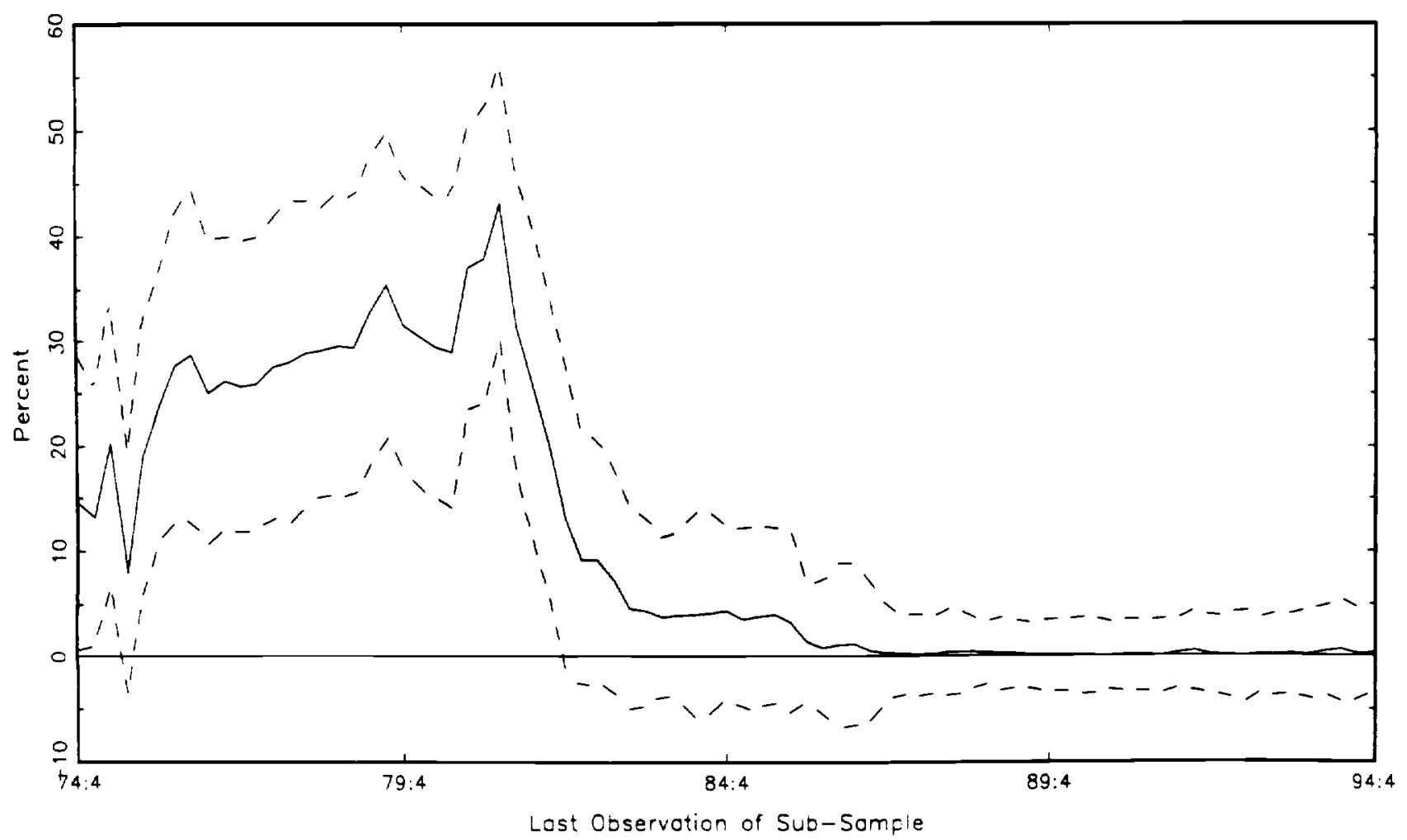


point moves from 1975 to 1995 look somewhat similar to those in Figure 1, especially for the effect of money on prices the indicated magnitudes are much larger (note the different vertical scales compared to Figure 1). The magnitudes are especially large for the percentage of the variance of prices accounted for by money as seen from vantage points before 1983, and they are also larger for the percentage of output as seen from vantage points between 1979 and 1987. Moreover, in contrast to what Figure 1 shows, here the effect of money on output is significant (in the modest sense implied by the one-standard-error band) for vantage points throughout 1979-1987, and the effect on prices is significant for vantage points during 1976-1983. In contradiction to Sims' finding, here introducing an interest rate into the regression system seems to magnify, and render more significant statistically, the resulting role of money in explaining subsequent output and price movements.

As Figure 4 shows, however, this contradiction does not carry over to direct tests of the predictive power of money as measured by the autoregression itself. Figure 4 presents series of p-values, analogous to those plotted in Figure 2, testing the null hypothesis that all coefficients $\delta_{i}$ are zero in the differenced equations

$$
\begin{aligned}
& \Delta x_{t}=\alpha+\sum_{t=1}^{4} \beta_{i} \Delta x_{t-i}+\sum_{i=1}^{4} \gamma_{i} \Delta p_{t-i}+\sum_{i=1}^{4} \delta_{i} \Delta m_{t-i}+\sum_{t=1}^{4} \theta_{i} \Delta r_{t-i}+u_{t} \\
& \Delta p_{t}=\alpha+\sum_{i=1}^{4} \beta_{i} \Delta x_{t-i}+\sum_{i=1}^{4} \gamma_{i} \Delta p_{t-i}+\sum_{i=1}^{4} \delta_{i} \Delta m_{t-i}+\sum_{t-1}^{4} \theta_{i} \Delta r_{t-i}+u_{t}
\end{aligned}
$$

where $r$ is the federal funds rate and all other variables are as in (1) and (2). As in Sims' results, the top panel of Figure 4 indicates that once the regression system takes the interest rate into account, money no longer has 
EIGURE 4

SIGNIFICANCE OF M1 IN PREDICTING OUTPUT AND PRICES FOR 101 SAMPLES (SYSTFY ALSO IHCLUDES ETDERAL EUNDS BATE)

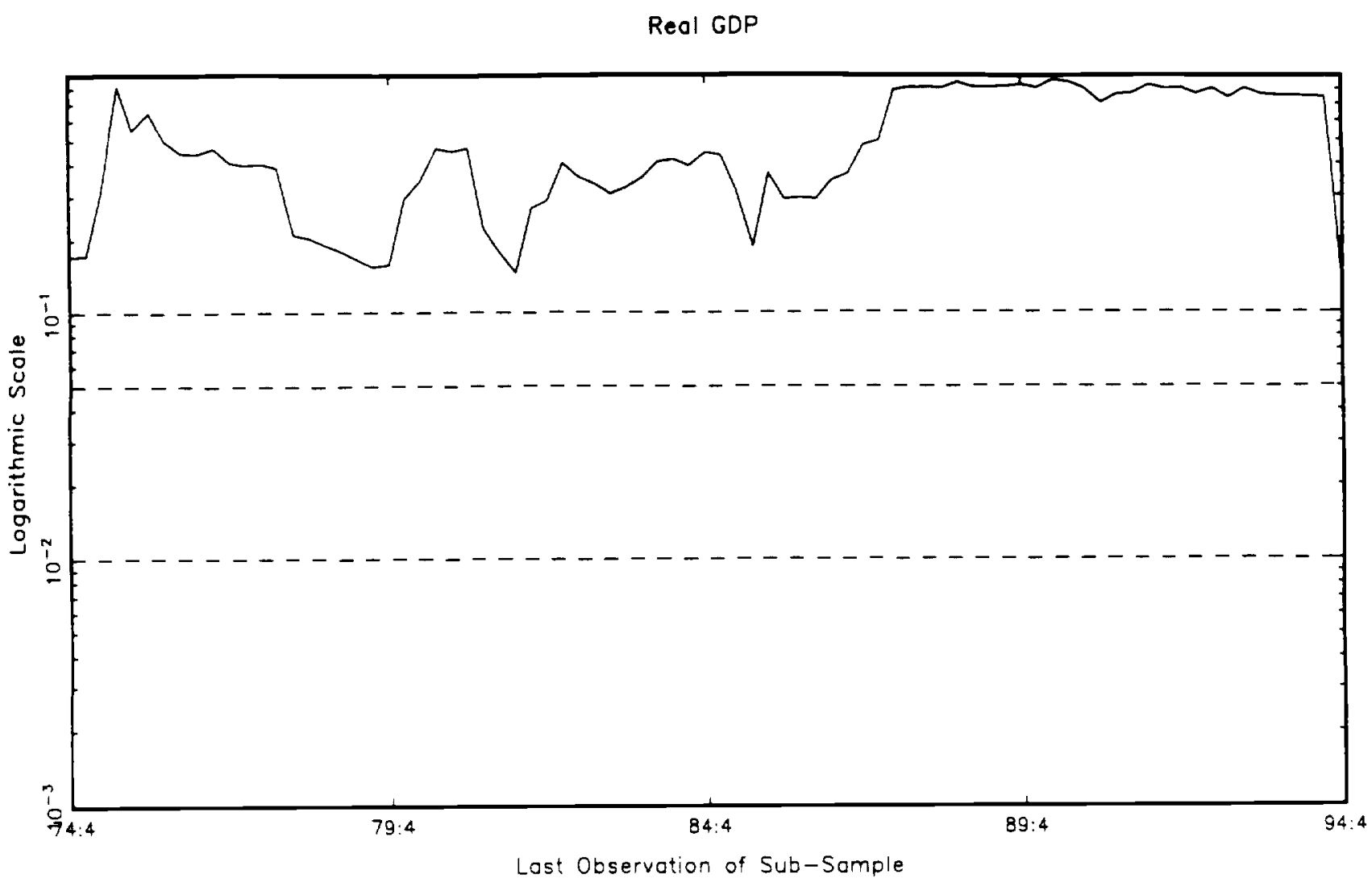

GDP Deflotor

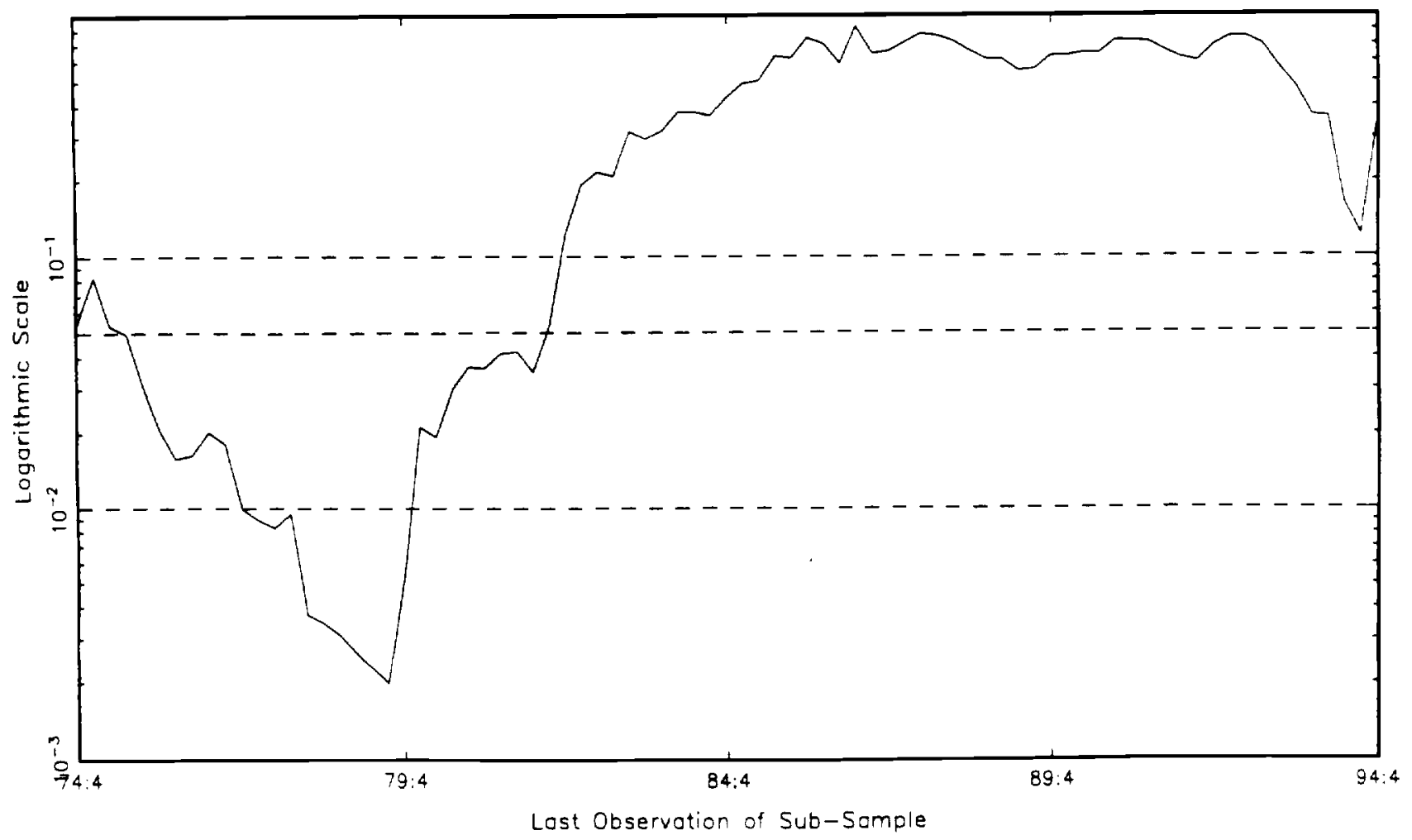


predictive power with respect to output that is significant even at the .10 level. Moreover, this finding holds for all 101 vantage points spanning the last twenty years. ${ }^{6}$ The significance of the predictive power of money with respect to prices is mostly unaffected compared to Figure 2, except for an effect, in the direction corresponding to sims' finding with respect to output, in the early 1980s.

Broad Money. M1, of course, is not the only monetary aggregate for which the Federal Reserve has established target rates of growth. Especially in more recent years, $M 2$ has replaced $M 1$ as the main center of attention for monetary policy purposes. Within the Federal Reserve, Feinman and Porter (1992) have argued on empirical grounds that M2 demand not only is more stable than the demand for other standard M's but also that M2 outperforms potential new candidate measures (for example, what others have called "liquid M2," consisting of currency plus all deposits in M2 that can be redeemed at par on demand). Outside the Federal Reserve, Ramey (1992) and Feldstein and Stock (1994) have argued that different forms of error-correction procedures render stable the ratio of $M 2$ to nominal income (or in reciprocal form, the mis-named M2 "velocity"). Before the 1993 "downgrading," the Federal Reserve's own public statements also attached more importance to M2 than to other aggregates.

Figures 5 and 6 present evidence for M2 that is analogous to that presented for M1 in Figures 1 and 2, respectively (and Appendix Figure A-3 shows results analgous to those in Figure $A-1$ ). What is striking in Figure 5 is the very large and significant role of $M 2$ in accounting for the subsequent variation of output, as seen from any vantage point from 1974 through 1991, and the extremely rapid decline in that role as seen from vantage points in the late 1980 s and especially after 1992. Figure 6 reinforces this result by showing that the predictive content of $M 2$ with respect to output as measured directly from the 
EIGURE $\underline{5}$

PERCENTAGES OF OUTPUT AND PRICE VARIATION ACCOUNTED FOR BY 12 AT A THO-YTAR HORIZON BOR 101 SAYPLES

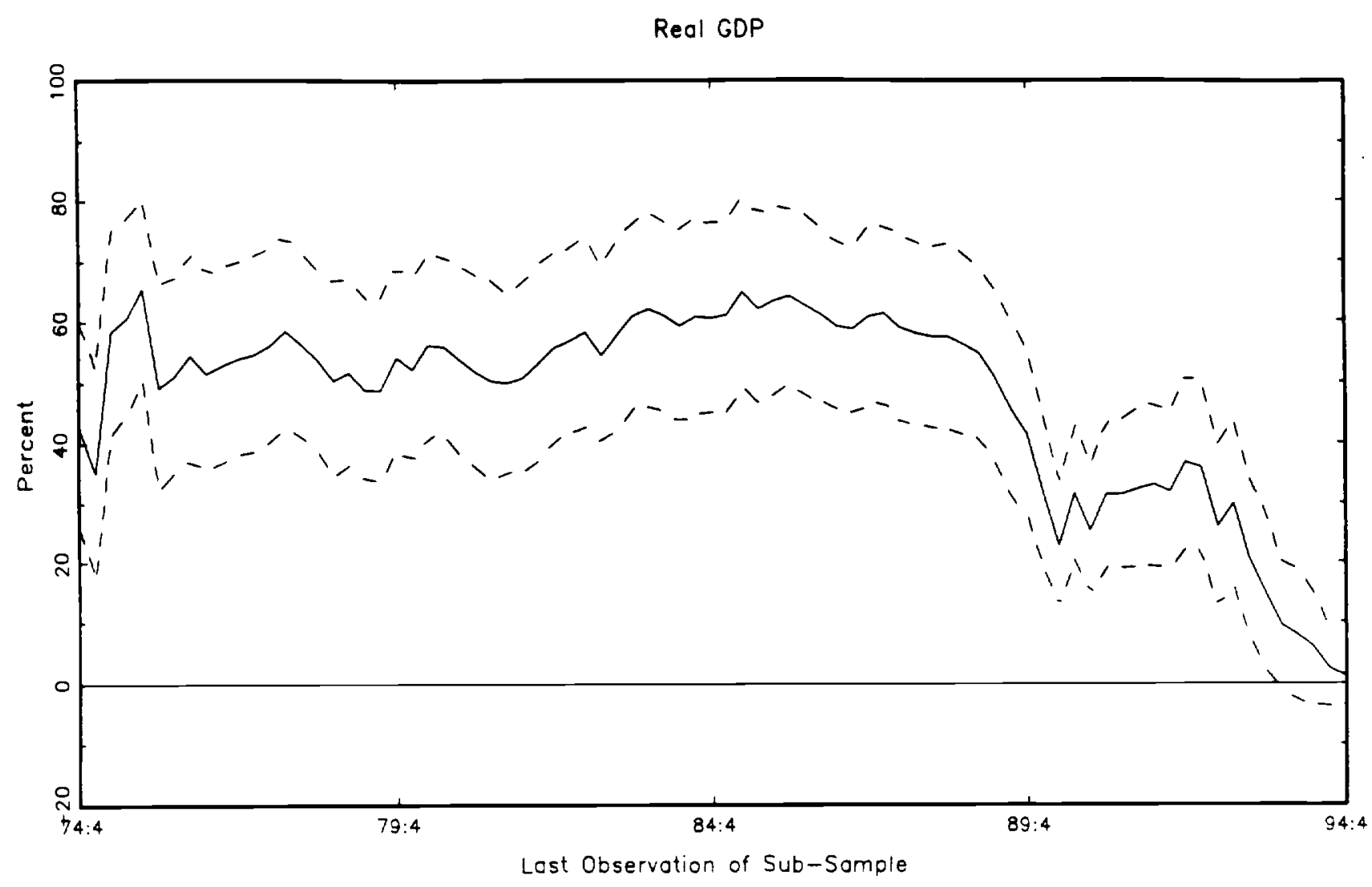

GDP Deflator

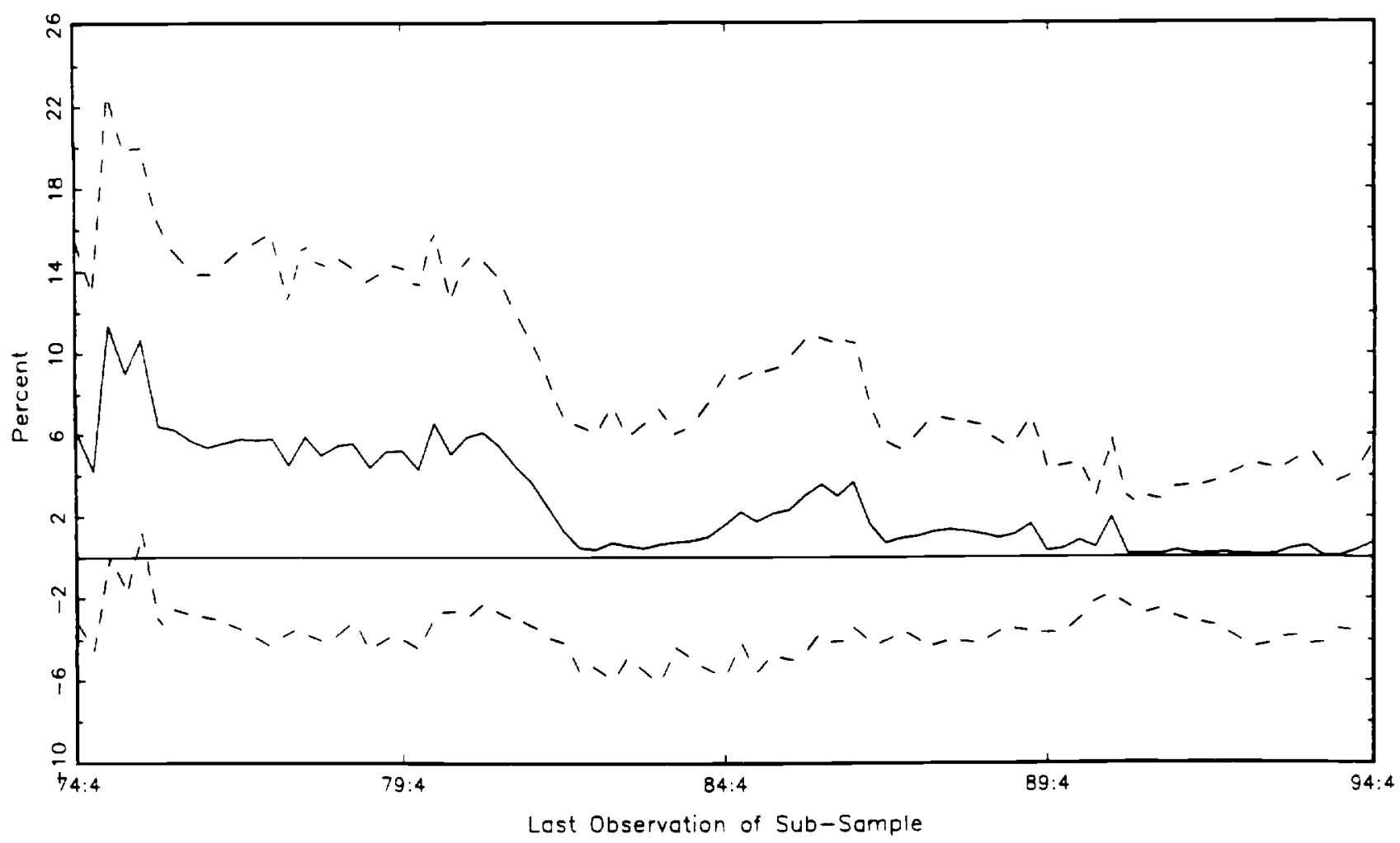


EIGURE 6

SIGAIFICANCE OF 12 IN RREDICTING OUTPUT AND RRICES FOR 101 SAYPLES

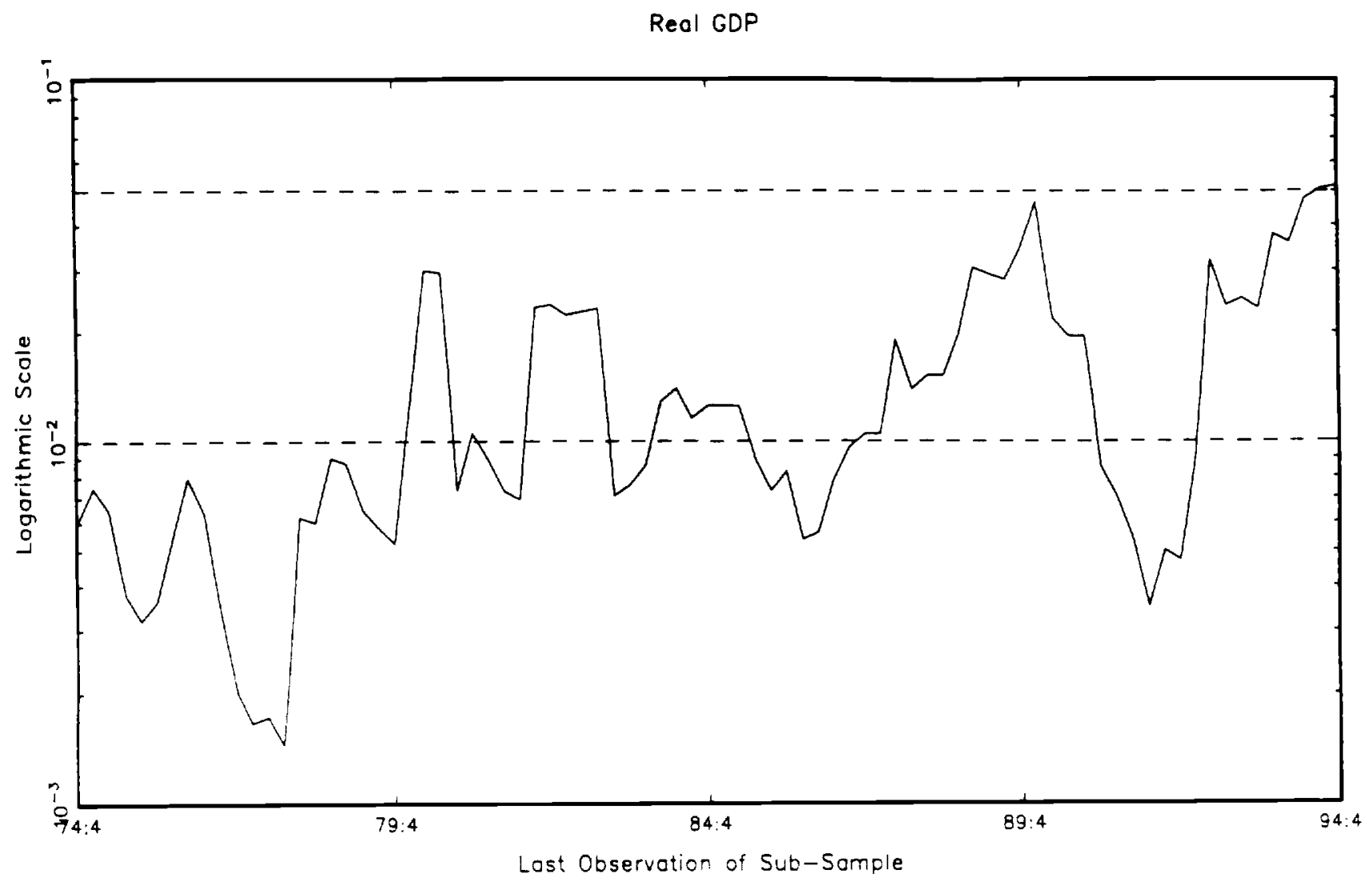

GDP Deflator

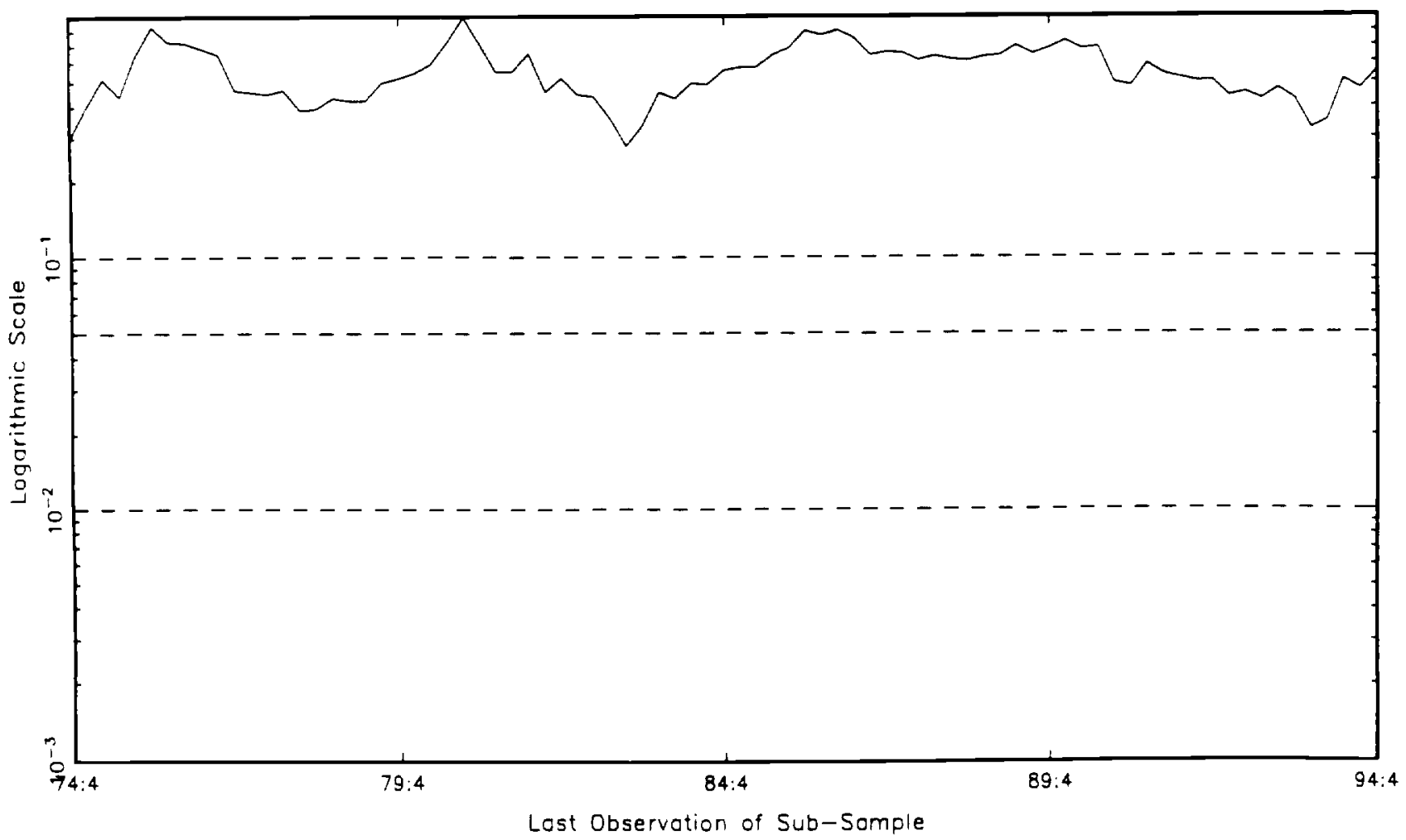


autoregression is significant at least at the .05 level for all vantage points until the most recent few (note that the top panel of Figure 6 highlights the .01 and .05 levels only). By contrast, M2 accounts for only a small and insignificant percentage of the subsequent variation of prices, especially for vantage points after 1975, and the directly measured predictive content of M2 with respect to prices is never significant even at the .10 level.

Once again, however, it is important to take interest rates into account in evaluating the contributions of money in this regard. Figures 7 and 8 (and Appendix Figure A-4) present results analogous to those in Figure 3 and 4 (and A-2), with M2 substituted for M1. Introducing the federal funds rate into the system makes no substantive difference for the role of M2 in accounting for prices, which was small and insignificant in the first place, but the results referring to output are reminiscent of Sims' finding. Introducing the interest rate consistently reduces the percentage of the variation of output attributable to $M 2$, although it still remains large as seen from some vantage points. It is also still statistically significant for vantage points during 1977-1988 and again during 1992-1993. By contrast, with the exception of a solitary vantage point at the end of 1975 , the predictive content of $M 2$ with respect to output as measured directly from the autoregression is never significant even at the .10 level.

Overview. Changes over time in money-output and money-price relationships like those documented in Figures 1-8 could, in principle, arise for any of several well known reasons. Most obviously, if the central bank had acted so as to reduce sharply the variance of money growth, with all else equal the predictive content of money would of course have declined. (In the limit, with zero variance, money would have zero predictive content.) Such is clearly not the case here, however, since in fact money growth became not less variable but 
EIGURE 1

PERCENTAGES OF OUTPUT AND PRICE VARIATION ACCOUNTED FOR BY 12

AT A TWO-YEAR HORIZON EOR 101 SAMPIES (SYSTEM ALSO INCLUDES EEDERAL EUNDS RATE)

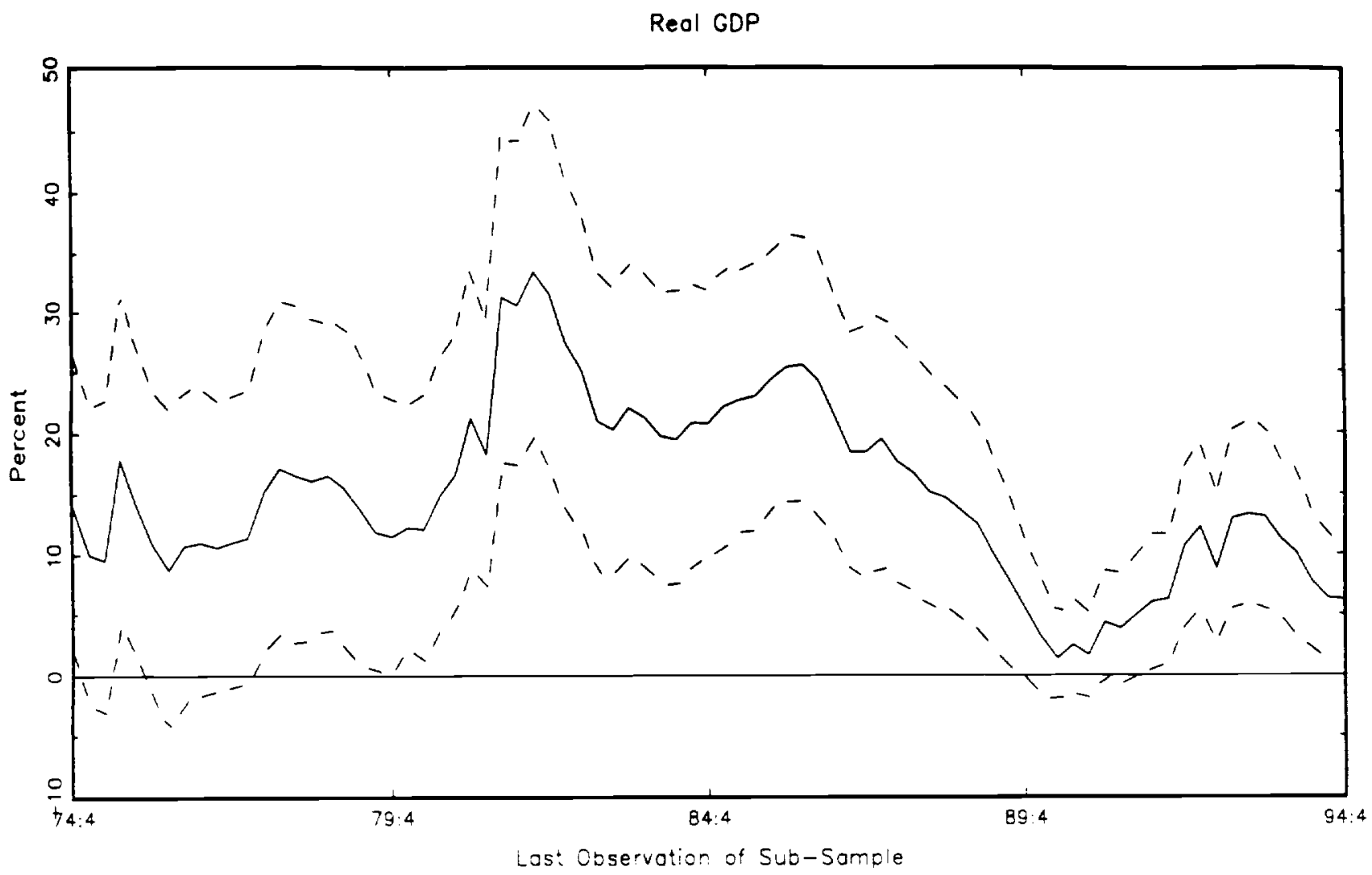

GDP Deflotor

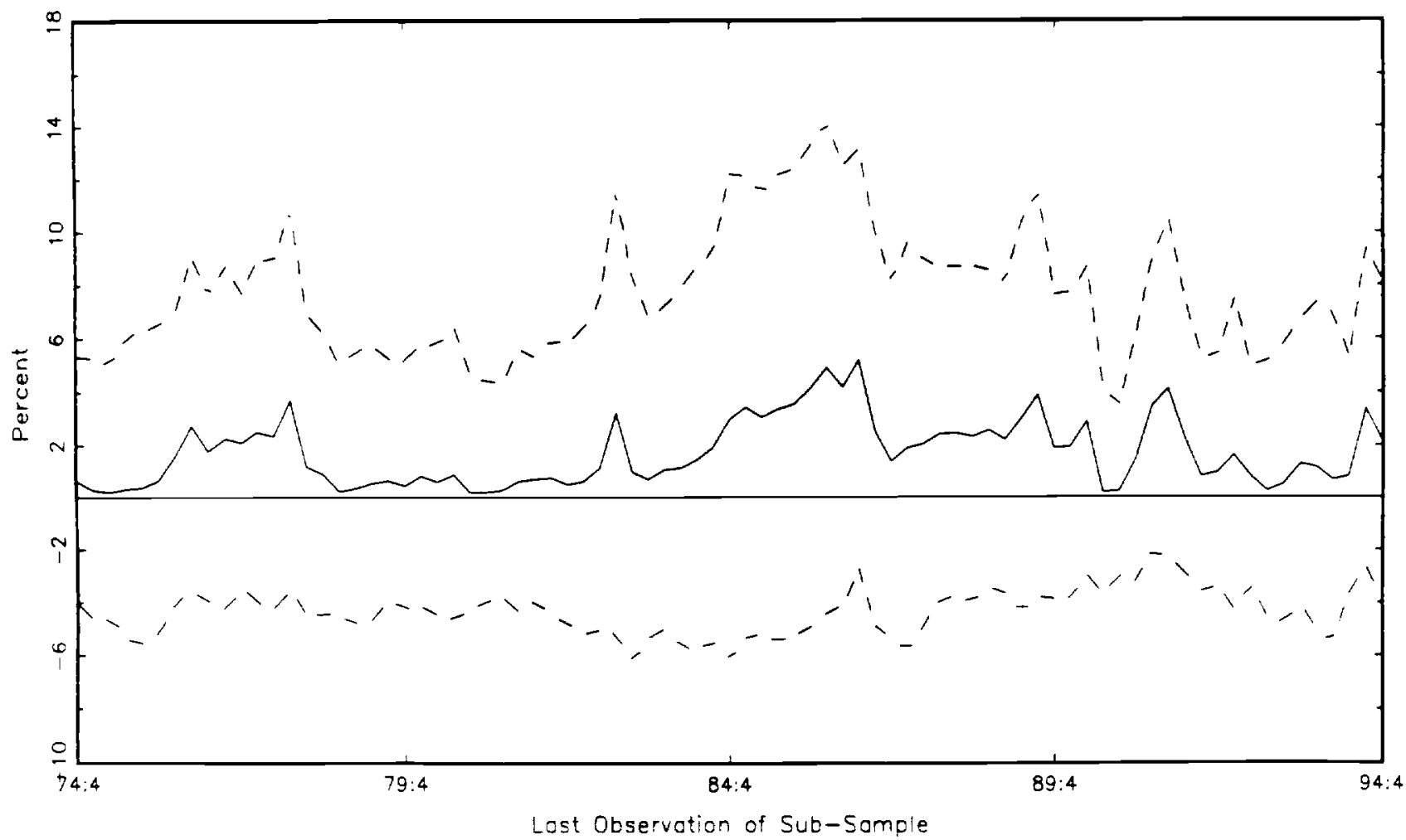


EIGURE $\underline{8}$

SIGNIFICANCE OF M2 IN BREDICTING OUTPUT AND BRICES FOR 101 SAMPLES (SYSTFY AISO IHCUUDES EBDPRAL RINDS BATE)

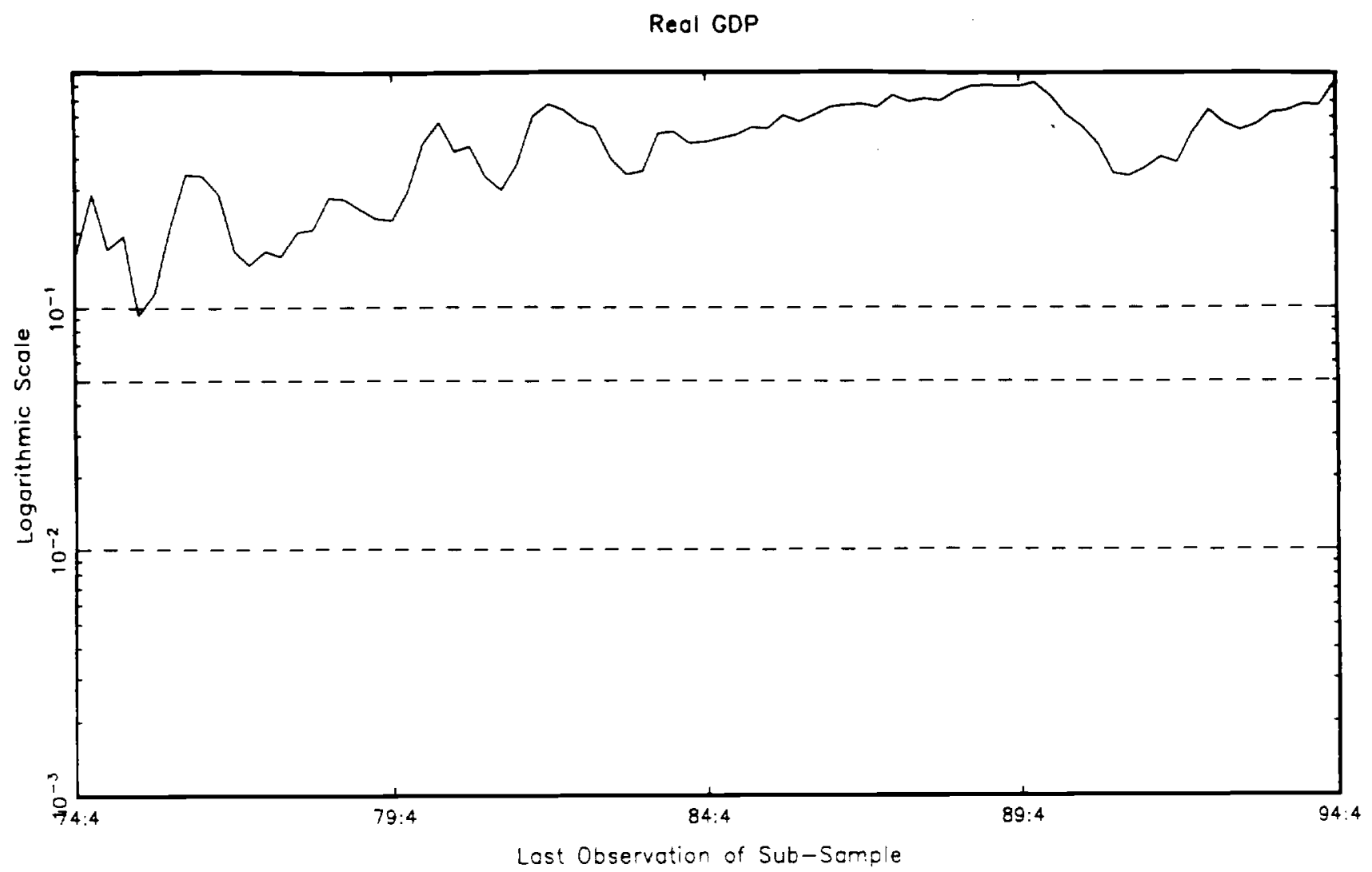

GOP Deflator

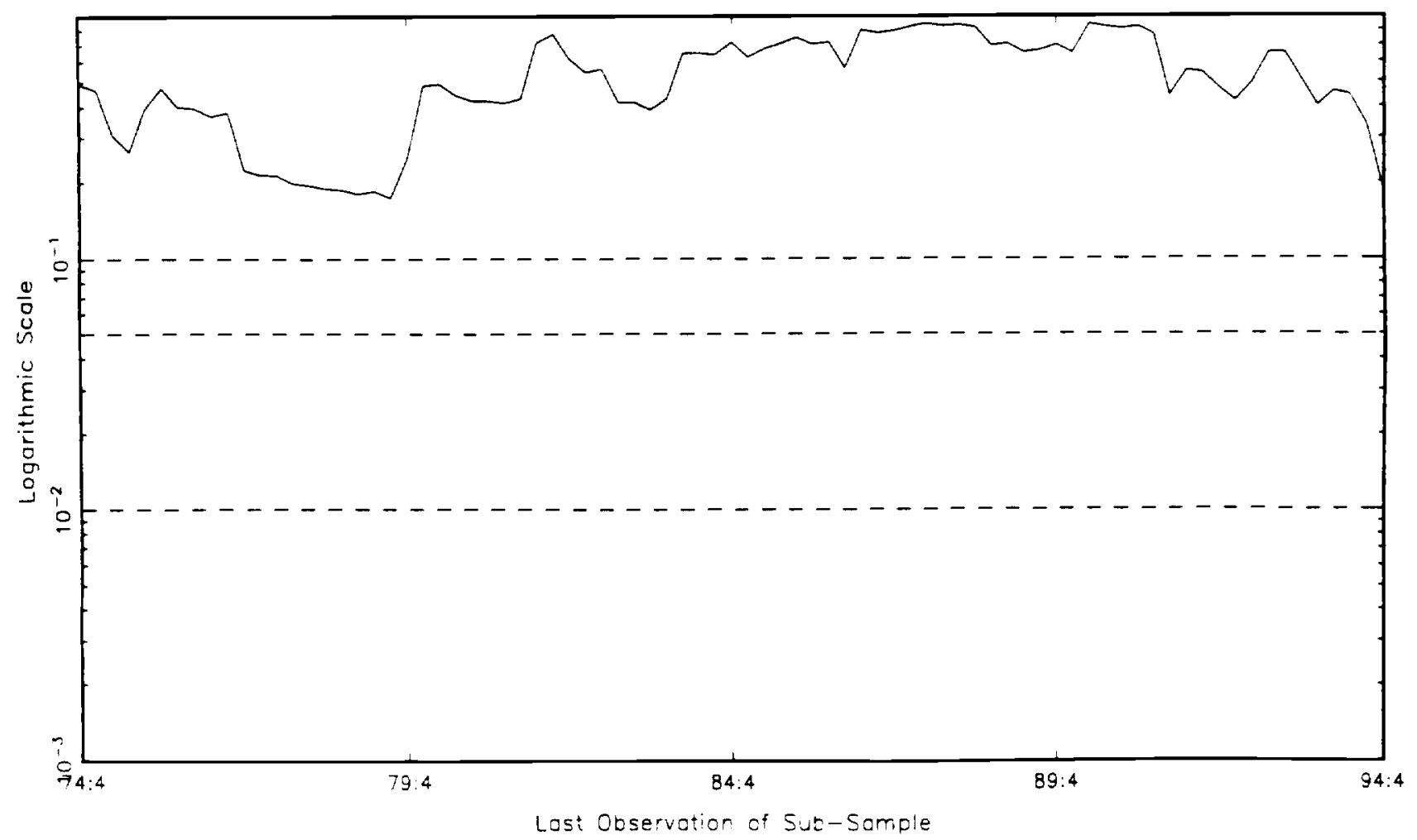


more so during some of the crucial periods in question (especially the mid 1980s).

Instead, the changes in the predictive content of money documented here reflect changes in economic behavior -- presumably including in particular the public's money demand behavior. Just why the relevant behavior changed is the focus of a large and heterogenous literature, and the question lies well beyond the scope of this paper. Familiar explanations that various researchers have suggested include changes in banking institutions, in regulations restricting allowable forms of deposits (most obviously the removal of Regulation $Q$ interest rate ceilings and the blurring of the traditional separation between transaction deposits and savings deposits), in macroeconomic conditions (for example, in the pace and persistence of inflation), and in financial technology. It is also possible that changes in the conduct of monetary policy themselves induced changes in deposit holding and other forms of behavior on the part of both businesses and households, which in turn caused changes in the predictive content of money. ${ }^{7}$ But whatever combination of such factors was responsible, such changes in the predictive content of money with respect to output and prices clearly affect the usefulness of money growth targets as guidelines for monetary policy. 
III. What Did They Do, and When Did They Do It?

Observing what central banks do is usually straight forward. Establishing why they have done it is more problematic. Central bank purchases and sales of securities, the resulting changes in bank reserves, and fluctuations in the relevant short-term interest rate are all known data not long after the fact. But few central banks make clear -. genuinely clear -. just why they have chosen the actions they have taken.

The usual critics notwithstanding, the problem in this regard reflects more than a mere preference for obfuscation. Under institutional arrangements like those at the Federal Reserve System, where the key decision-making authority rests in a sizeable committee (the Open Market Committee has twelve voting members), different participants in the policy process may have differing reasons for favoring the same action. Requiring them to agree not only on what to do but on a precise statement of why they choose to do it would significantly raise the hurdle facing a policymaking process that must play out in real time. The situation is even more complicated because the Federal Reserve is legally responsible to the Congress, which historically has been not only vague and inconsistent in stating its objectives for monetary policy but also slow to alter its formal changes to the Federal Reserve as economic circumstances have changed.

Has the Federal Reserve, then, actually attempted to implement its stated money growth targets? And if so, how would one know?

To recall from Section $I$, if there were never any disturbances to the relationships connecting money growth to prices and output, pursuing a money growth target at the second stage of the implied two-level policy process would be indistinguishable from simply varying the interest rate or the quantity of reserves so as to come as close as possible to achieving the desired objectives 
for prices and output themselves. The approach taken here to inferring whether the Federal Reserve's money growth targets have actually affected its monetary policy actions is therefore to look for independent effects of fluctuations in money, relative to the stated growth target, that are not already accounted for by prices and real economic activity. In particular, Taylor (1993) has argued that a simple formula relating the level of the federal funds rate to price inflation and the level of real activity relative to trend has approximately characterized U.S. monetary policy in recent years. The approach taken here is to ask whether, and when -. in addition, -. the federal funds rate has also responded to departures of money from the stated target.

Narrow Money. The first row of Table 1 presents estimated coefficient values and t-statistics for the regression

$$
\mathbf{r}_{t}=\alpha+\beta \pi_{t-1}+\gamma(\mathrm{U}-\mathrm{U} *)_{t-1}+u_{t}
$$

based on monthly U.S. data for the sample beginning in 1960:2 and ending in 1975:4 - - that is, just before the Federal Reserve had a stated money growth target. Here $r$ is the federal funds rate, $\pi$ is the inflation rate measured over the preceding twelve months, $U$ is the unemployment rate, and $U *$ is Gordon's (1993) estimate of the "natural" rate of unemployment. ${ }^{8}$ (Taylor's formula instead uses the deviation of real output from trend, but establishing the appropriate output trend is problematic over as long a time period as is ultimately treated here.) All variables are in units corresponding to "percent."

The estimates for (5) shown in the first row of Table 1 are consistent with standard interpretations of monetary policy behavior. ${ }^{9}$ Faster inflation leads the Federal Reserve to set a higher interest rate, although the less-than-unit 
MONETARY POLICY REACTION FUNCTIONS ALLOWING FOR M1 GROWTH TARGETS

\begin{tabular}{|c|c|c|c|c|c|}
\hline End of Sample & $\alpha$ & $\mathrm{B} \pi$ & $x\left(U-U^{*}\right)$ & $\theta(1-D)\left(m-m^{T}\right)$ & $\underline{\delta} \cdot \mathrm{D}\left(\mathrm{m}-\mathrm{m}^{\mathrm{T}}\right)$ \\
\hline $75: 4$ & $\begin{array}{l}2.201 \\
(10.7)\end{array}$ & $\begin{array}{l}0.712 \\
(14.7)\end{array}$ & $\begin{array}{l}-0.866 \\
(-8.3)\end{array}$ & -- & $\begin{array}{l}- \\
-\end{array}$ \\
\hline $75: 12$ & $\begin{array}{l}2.226 \\
(11.0)\end{array}$ & $\begin{array}{l}0.702 \\
(16.0)\end{array}$ & $\begin{array}{l}-0.880 \\
(-10.0)\end{array}$ & $\begin{array}{l}-- \\
--\end{array}$ & $\begin{array}{l}-0.122 \\
(-0.1)\end{array}$ \\
\hline $76: 12$ & $\begin{array}{l}2.226 \\
(11.3)\end{array}$ & $\begin{array}{l}0.701 \\
(16.7)\end{array}$ & $\begin{array}{l}-0.883 \\
(-11.1)\end{array}$ & $\begin{array}{l}-0.123 \\
(-0.1)\end{array}$ & $\begin{array}{l}0.161 \\
(0.2)\end{array}$ \\
\hline $77: 12$ & $\begin{array}{l}2.224 \\
(11.6)\end{array}$ & $\begin{array}{l}0.700 \\
(17.2)\end{array}$ & $\begin{array}{l}-0.888 \\
(-11.6)\end{array}$ & $\begin{array}{l}0.053 \\
(0.1)\end{array}$ & $\begin{array}{l}0.459 \\
(0.5)\end{array}$ \\
\hline $78: 12$ & $\begin{array}{l}2.189 \\
(11.7)\end{array}$ & $\begin{array}{l}0.718 \\
(18.4)\end{array}$ & $\begin{array}{l}-0.888 \\
(-12.1)\end{array}$ & $\begin{array}{l}0.163 \\
(0.3)\end{array}$ & $\begin{array}{l}1.005 \\
(1.5)\end{array}$ \\
\hline $79: 12$ & $\begin{array}{l}2.139 \\
(11.7)\end{array}$ & $\begin{array}{l}0.737 \\
(19.7)\end{array}$ & $\begin{array}{l}-0.894 \\
(-12.3)\end{array}$ & $\begin{array}{l}0.430 \\
(1.1)\end{array}$ & $\begin{array}{l}0.861 \\
(5.2)\end{array}$ \\
\hline $80: 12$ & $\begin{array}{l}1.706 \\
(9.0)\end{array}$ & $\begin{array}{l}0.868 \\
(24.7)\end{array}$ & $\begin{array}{l}-0.905 \\
(-11.4)\end{array}$ & $\begin{array}{l}0.553 \\
(3.3)\end{array}$ & $\begin{array}{l}2.191 \\
(7.0)\end{array}$ \\
\hline $81: 12$ & $\begin{array}{l}1.384 \\
(5.5)\end{array}$ & $\begin{array}{l}0.997 \\
(22.2)\end{array}$ & $\begin{array}{l}-0.752 \\
(-7.1)\end{array}$ & $\begin{array}{l}0.622 \\
(3.1)\end{array}$ & $\begin{array}{l}3.942 \\
(4.9)\end{array}$ \\
\hline $82: 12$ & $\begin{array}{l}1.398 \\
(5.2)\end{array}$ & $\begin{array}{l}1.013 \\
(21.5)\end{array}$ & $\begin{array}{l}-0.644 \\
(-5.9)\end{array}$ & $\begin{array}{l}0.744 \\
(3.6)\end{array}$ & $\begin{array}{l}2.040 \\
(6.5)\end{array}$ \\
\hline 83.12 & $\begin{array}{l}1.926 \\
(7.2)\end{array}$ & $\begin{array}{l}0.933 \\
(19.7)\end{array}$ & $\begin{array}{l}-0.262 \\
(-2.8)\end{array}$ & $\begin{array}{l}1.021 \\
(5.6)\end{array}$ & $\begin{array}{l}3.299 \\
(4.9)\end{array}$ \\
\hline $84: 12$ & $\begin{array}{l}2.231 \\
(8.4)\end{array}$ & $\begin{array}{l}0.893 \\
(18.8)\end{array}$ & $\begin{array}{l}-0.114 \\
(-1.3)\end{array}$ & $\begin{array}{l}1.076 \\
(5.9)\end{array}$ & $\begin{array}{l}4.694 \\
(4.0)\end{array}$ \\
\hline $85: 12$ & $\begin{array}{l}2.353 \\
(8.9)\end{array}$ & $\begin{array}{l}0.883 \\
(18.6)\end{array}$ & $\begin{array}{l}-0.071 \\
(-0.8)\end{array}$ & $\begin{array}{l}1.104 \\
(6.1)\end{array}$ & $\begin{array}{l}0.802 \\
(2.2)\end{array}$ \\
\hline $86: 12$ & $\begin{array}{l}2.366 \\
(9.2)\end{array}$ & $\begin{array}{l}0.885 \\
(19.1)\end{array}$ & $\begin{array}{l}-0.061 \\
(-0.7)\end{array}$ & $\begin{array}{l}1.036 \\
(6.3)\end{array}$ & $\begin{array}{l}0.102 \\
(0.7)\end{array}$ \\
\hline
\end{tabular}

Notes: Numbers in parentheses are t-statistics.

Gap between actual and target $M 1$ is measured from the mid-point of the designated target range. 
value of $\beta$ supports the familiar criticism that in the 1960 s and 1970 s the magnitude of this response was not sufficient to prevent procyclical fluctuation of the real interest rate. Higher unemployment (relative to the "natural" rate) leads to a lower interest rate. The coefficients on both variables are highly significant.

The Federal Reserve's first formally stated money growth targets specified growth ranges for the M1, M2 and M3 aggregates over the one-year period from March 1975 to March 1976. April 1975 was therefore the first month in which the actual value of any given measure of money could be compared to the value implied by corresponding growth target. With a one-month observation lag, May 1975 was therefore the first month in which success or failure in achieving its money growth target could plausibly have influenced the Federal Reserve's setting of the federal funds rate.

The second row of Table 1 presents estimates for the expanded regression

$$
r_{t}=\alpha+\beta \pi_{t-1}+\gamma\left(U-U^{*}\right)_{t-1}+\delta\left(m-m^{T}\right)_{t-1}+u_{t}
$$

based on monthly data for sample beginning in 1960:2 and ending in 1975:12. Here $m$ is the logarithm of the Ml money stock, $m^{T}$ is the logarithm of the corresponding value constructed by tracing out the growth path implied by the mid-point of the designated target range, and all other variables are as in (5). More specifically, both $\mathrm{m}$ and $\mathrm{m}^{\mathrm{T}}$ refer to the definition of $\mathrm{Ml}$ in use in 1975 , and the data used for $m$ and used to construct $\mathrm{m}^{\mathrm{T}}$ are taken from Federal Reserve sources dated in early 1976. (For purposes of this exercise it is essential to estimate the regression using data that correspond to what policymakers saw and construed as $M 1$ at the time, rather than the standard data available today. ${ }^{10}$ )

The Federal Reserve did not have a formal money growth target in effect 
before April 1975 - that is, $\mathrm{m}^{\mathrm{T}}$ did not exist - - and so for purposes of the regression $\left(m-m^{T}\right)$ simply assumes the value zero for all months in the sample through 1975:3. For 1975:4-1975:5, $\mathrm{m}^{\mathrm{T}}$ is defined by tracing out for those two months the growth path implied by the $61 / 48$ per annum mid-point of the $5-71 / 28$ M1 growth target specified for the period running from the first quarter of 1975 to the corresponding quarter of 1976. In June 1975 the Federal Reserve moved forward the base from which it was targeting the monetary aggregates and also shifted to a quarterly computation basis, so that the new targets specified growth ranges for the period 1975:II to 1976:II. For purposes of the regression, therefore, $\mathrm{m}^{\mathrm{T}}$ for 1975:6-1975:8 is defined by the monthly values along the path implied by the mid-point of this new M1 growth target (again 5-7 1/28 per annum, but from the 1975:II base). Similarly, $m^{T}$ for 1975:9-1975:11 is defined from the mid-point of the next new target for Ml growth, set in September for the period 1975:III-1976:III (yet again 5-7 1/28 per annum, but now from the 1975 : III base).

As the second row of Table 1 shows, the resulting estimate of $\delta$ for the eight months of 1975 in which the Federal Reserve might have reacted to M1 growth in relation to the corresponding target path provides no evidence that the Federal Reserve actually did so. The estimated coefficient is not only small and statistically insignificant but of the wrong sign to reflect behavior consistent with targeting money growth. (If the central bank were actually targeting money, it would presumably increase the interest rate when money is above target, not lower it.)

The third row of Table 1 presents estimates for the further expanded regression

$$
r_{t}=\alpha+\beta \pi_{t-1}+\gamma(U-U *)_{t-1}+\delta\left(m-m^{T}\right)_{t-1} \cdot D+\theta\left(m-m^{T}\right)_{t-1} \cdot(1-D)+u_{t}
$$


for the sample beginning in 1960:2 and ending in 1976:12. Here $D$ is a dummy variable equal to 1 in the twelve months of 1976 and zero before, so that the two separate $\left(m-m^{T}\right)$ terms in the regression distinguish the Federal Reserve's attempt to target money growth in 1976 from that earlier on. Subsequent rows present analogous estimates of (7) for samples ending in 1977:12, 1978:12, and so on through 1986:12. In each regression D takes on the value 1 in the twelve final months of the sample and zero before. ${ }^{11}$ Throughout, values of $\mathrm{m}$ correspond to the definition of $M 1$ in use in the particular year in question. ${ }^{12}$ For 1976:1-1978:11, values of $\mathrm{m}^{\mathrm{T}}$ are defined from the successive mid-points of the rolling annual growth targets that the Federal Reserve established on a quarterly basis. For 1978:12-1986:12, $\mathrm{m}^{\mathrm{T}}$ is defined from the mid-point of the successive annual target ranges (in some years called "monitoring ranges") established once per year (and as amended during the year in 1983 and 1985). The Federal Reserve has not designated a formal growth target for Ml since 1986. For 1976, 1977 and 1978 the estimates shown in successive rows of Table 1 provide steadily stronger hints -. to say "evidence" would be exaggerating .. that the Federal Reserve was taking account of its Ml target in setting the federal funds rate. Unlike the result for 1975 , the estimated values of $\delta$ are positive and becoming more so year by year -- just what would be expected if (7) is identified as a monetary policy reaction function, and just the opposite of what would be implied if the equation were instead an inverted money demand function. Although the t-statistic steadily increases, however, none of these estimates meets the standard .05 significance level.

By contrast, for every year from 1979 through 1984 the estimated value of $\delta$ is both large and highly significant. ${ }^{13}$ For 1979, for example, the estimated $\delta$ implies that, for given rates of inflation and unemployment, the Federal Reserve set the interest rate .86 percentage point ( 86 basis points) higher for every 
one percent that $M 1$ was above its target in the preceding month. The estimated response is much larger from 1980 through 1984. For 1985 the estimated $\delta$ is smaller but still marginally significant. For 1986 there is no longer any evidence that the Federal Reserve was actually targeting M1 growth.

Although it is not the subject of this paper, a further notable feature of the results presented in Table 1 is the disappearance, after about 1983, of real activity (here measured by unemployment relative to Gordon's natural rate) as a visible influence on monetary policy. This change over time is interesting in its own right and deserves attention in a separate paper. By contrast, inflation on balance increases as an influence on monetary policy during this period. 14

The regressions reported in Table 1 rely on a construction of the key $\left(m-m^{T}\right)$ variable in which $m^{T}$ is defined from the mid-point of the designated target range for $M 1$. As a result, $\left(m-m^{T}\right)$ is a continuous variable and both (6) and (7) implicitly assume that the Federal Reserve's response to a deviation of M1 from the mid-point of the target range does not specifically depend on whether observed money is within the range or outside it.

Table 2 presents analogous results based on an alternative representation of Federal Reserve behavior that distinguishes discontinuously between values of money that are within or outside the target range. Here $\left(m-m^{T}\right)$ is set equal to zero whenever observed money is within the corresponding range. For observations outside the range, $\left(\mathrm{m}-\mathrm{m}^{\mathrm{T}}\right)$ equals the algebraic difference between $\mathrm{m}$ and the monthly path implied by either the upper or the lower end of the designated range, whichever is closer. The final column of Table 2 indicates, for each year, the number of monthly observations for which money was outside the target range and for which $\left(m-m^{T}\right)$ therefore takes on non-zero value.

Although in principle this alternative representation of (m-m $\mathrm{m}^{\mathrm{T}}$ ) could lead 
TABLE 2

MONETARY POLICY REACTION FUNCTIONS ALLOWING FOR M1 GROWTH TARGETS (DISTINGUISHING MONEY IN OR OUT OF TARGET RANGE)

\begin{tabular}{|c|c|c|c|c|c|c|}
\hline End of Sample & $\alpha$ & $\mathrm{B} \pi$ & $x\left(U-U^{*}\right)$ & $\theta(1-D)\left(m-m^{T}\right)$ & $\delta \cdot D\left(m-m^{T}\right)$ & $\begin{array}{c}\text { Months Out } \\
\text { of Range }\end{array}$ \\
\hline $75: 4$ & $\begin{array}{l}2.201 \\
(10.7)\end{array}$ & $\begin{array}{l}0.712 \\
(14.7)\end{array}$ & $\begin{array}{l}-0.866 \\
(-8.2)\end{array}$ & $\begin{array}{l}- \\
--\end{array}$ & $\begin{array}{l}- \\
-\end{array}$ & $\begin{array}{l}\cdots \\
\cdots\end{array}$ \\
\hline $75: 12$ & $\begin{array}{l}2.226 \\
(11.0)\end{array}$ & $\begin{array}{l}0.701 \\
(16.0)\end{array}$ & $\begin{array}{l}-0.881 \\
(-10.0)\end{array}$ & $\begin{array}{l}- \\
-\end{array}$ & $\begin{array}{l}-0.319 \\
(-0.2)\end{array}$ & $\begin{array}{l}8 \\
--\end{array}$ \\
\hline $76: 12$ & $\begin{array}{l}2.225 \\
(11.3)\end{array}$ & $\begin{array}{l}0.700 \\
(16.7)\end{array}$ & $\begin{array}{l}-0.884 \\
(-11.1)\end{array}$ & $\begin{array}{l}-0.324 \\
(-0.2)\end{array}$ & $\begin{array}{l}0.282 \\
(0.2)\end{array}$ & $\begin{array}{l}9 \\
-\end{array}$ \\
\hline 77.12 & $\begin{array}{l}2.225 \\
(11.6)\end{array}$ & $\begin{array}{l}0.701 \\
(17.2)\end{array}$ & $\begin{array}{l}-0.886 \\
(-11.7)\end{array}$ & $\begin{array}{l}0.049 \\
(0.1)\end{array}$ & $\begin{array}{l}0.566 \\
(0.4)\end{array}$ & 10 \\
\hline $78: 12$ & $\begin{array}{l}2.184 \\
(11.7)\end{array}$ & $\begin{array}{l}0.720 \\
(18.5)\end{array}$ & $\begin{array}{l}-0.888 \\
(-12.1)\end{array}$ & $\begin{array}{l}0.181 \\
(0.2)\end{array}$ & $\begin{array}{l}1.235 \\
(1.3)\end{array}$ & 10 \\
\hline $79: 12$ & $\begin{array}{l}2.127 \\
(11.6)\end{array}$ & $\begin{array}{l}0.741 \\
(19.9)\end{array}$ & $\begin{array}{l}-0.895 \\
(-12.3)\end{array}$ & $\begin{array}{l}0.538 \\
(0.9)\end{array}$ & $\begin{array}{l}1.245 \\
(5.1)\end{array}$ & 10 \\
\hline $80: 12$ & $\begin{array}{l}1.661 \\
(8.6)\end{array}$ & $\begin{array}{l}0.883 \\
(24.7)\end{array}$ & $\begin{array}{l}-0.902 \\
(-11.1)\end{array}$ & $\begin{array}{l}0.761 \\
(3.0)\end{array}$ & $\begin{array}{l}3.503 \\
(6.1)\end{array}$ & $\begin{array}{l}8 \\
--\end{array}$ \\
\hline $81: 12$ & $\begin{array}{l}1.362 \\
(5.2)\end{array}$ & $\begin{array}{l}1.009 \\
(22.0)\end{array}$ & $\begin{array}{l}-0.745 \\
(-6.8)\end{array}$ & $\begin{array}{l}0.799 \\
(2.6)\end{array}$ & $\begin{array}{l}4.069 \\
(3.5)\end{array}$ & $\begin{array}{l}6 \\
--\end{array}$ \\
\hline $82: 12$ & $\begin{array}{l}1.428 \\
(5.3)\end{array}$ & $\begin{array}{l}1.018 \\
(21.4)\end{array}$ & $\begin{array}{l}-0.587 \\
(-5.4)\end{array}$ & $\begin{array}{l}0.928 \\
(2.9)\end{array}$ & $\begin{array}{l}2.734 \\
(5.8)\end{array}$ & 12 \\
\hline $83: 12$ & $\begin{array}{l}1.991 \\
(7.4)\end{array}$ & $\begin{array}{l}0.933 \\
(19.4)\end{array}$ & $\begin{array}{l}-0.198 \\
(-2.1)\end{array}$ & $\begin{array}{l}1.328 \\
(4.8)\end{array}$ & $\begin{array}{l}4.020 \\
(3.9)\end{array}$ & $\begin{array}{l}6 \\
--\end{array}$ \\
\hline $84: 12$ & $\begin{array}{l}2.281 \\
(8.4)\end{array}$ & $\begin{array}{l}0.901 \\
(18.5)\end{array}$ & $\begin{array}{l}-0.061 \\
(-0.7)\end{array}$ & $\begin{array}{l}1.364 \\
(4.9)\end{array}$ & $\begin{array}{r}17.033 \\
(2.1)\end{array}$ & $\begin{array}{l}3 \\
--\end{array}$ \\
\hline $85: 12$ & $\begin{array}{l}2.368 \\
(8.8)\end{array}$ & $\begin{array}{l}0.895 \\
(18.5)\end{array}$ & $\begin{array}{l}-0.027 \\
(-0.3)\end{array}$ & $\begin{array}{l}1.331 \\
(4.8)\end{array}$ & $\begin{array}{l}1.063 \\
(2.0)\end{array}$ & $\begin{array}{l}9 \\
--\end{array}$ \\
\hline $86: 12$ & $\begin{array}{l}2.390 \\
(9.1)\end{array}$ & $\begin{array}{l}0.894 \\
(19.0)\end{array}$ & $\begin{array}{l}-0.017 \\
(-0.2)\end{array}$ & $\begin{array}{l}1.260 \\
(5.1)\end{array}$ & $\begin{array}{l}0.107 \\
(0.5)\end{array}$ & 10 \\
\hline
\end{tabular}

Notes: Numbers in parentheses are t-statistics.

Gap between actual and target $M 1$ is measured from the the near boundary of the designated target range. 
to different implied behavior by the Federal Reserve, in fact the results shown in Table 2 are highly similar to those in Table 1. The one eye-catching difference is the out-sized estimated value of $\delta$ for 1984 in Table 2 . As the table indicates, however, Ml was outside the designated target range in only three months of 1984, and so the empirical basis underlying this particular estimate is very slender.

Broad Money. Table 3 presents results that are directly analogous to those in Table 1 but based on values and growth targets for the M2 money stock. (Once again, the definitions and observed values for the M2 aggregate for each year are those actually in use at the time.) Because the Federal Reserve has continued to designate growth targets for $M 2$ through the present day, instead of stopping with the 1960:2-1986:12 sample as in Table 1 the estimates presented in Table 2 continue through the sample ending in 1994:12. Interesting aspects of the results for these later years are the evidence of a continuing strong role of inflation as an influence guiding monetary policy, and the continuing absence of evidence of such a role for real economic activity after 1982 .

The results shown in Table 3 suggest that the Federal Reserve has actively attempted to target M2 growth during three separate time periods: during 1979-1981 (and, more marginally, 1978); in 1985; and during 1992-1993 (and, more marginally, 1991). In most of the other years, the estimated value of $\delta$ is negative, indicating that the monetary policy was simply accommodating the demand for M2 (so that (6) or (7) becomes an inverted money demand equation). For each of 1982, 1984 and 1989, the negative coefficient indicating this kind of accommodative policy is highly significant.

Finally, Table 4 presents results for $M 2$ based on the same discontinuous construction of the $\left(m-m^{T}\right)$ variable used for $M 1$ in Table 2. As is the case for M1, the alternative representation of the Federal Reserve's response to observed 
TABLE 3

MONETARY POLICY REACTION FUNCTIONS ALLOWING FOR M2 GROWTH TARGETS

\begin{tabular}{|c|c|c|c|c|c|}
\hline End of Sample & $\alpha$ & $\mathrm{B} \pi$ & $x\left(U-U^{*}\right)$ & $\theta(1-D)\left(m-m^{T}\right)$ & $\delta \cdot D\left(m-m^{T}\right)$ \\
\hline $75: 4$ & $\begin{array}{l}2.201 \\
(10.7)\end{array}$ & $\begin{array}{l}0.712 \\
(14.7)\end{array}$ & $\begin{array}{l}-0.866 \\
(-8.3)\end{array}$ & $\begin{array}{l}-- \\
--\end{array}$ & $\begin{array}{l}\cdots \\
\cdots\end{array}$ \\
\hline $75: 12$ & $\begin{array}{l}2.226 \\
(11.0)\end{array}$ & $\begin{array}{l}0.702 \\
(15.9)\end{array}$ & $\begin{array}{l}-0.880 \\
(-10.0)\end{array}$ & $\begin{array}{l}\cdots \\
\cdots\end{array}$ & $\begin{array}{c}-0.164 \\
(-0.1)\end{array}$ \\
\hline $76: 12$ & $\begin{array}{l}2.226 \\
(11.3)\end{array}$ & $\begin{array}{l}0.701 \\
(17.0)\end{array}$ & $\begin{array}{l}-0.881 \\
(-10.8)\end{array}$ & $\begin{array}{l}-0.163 \\
(-0.1)\end{array}$ & $\begin{array}{l}-0.148 \\
(-0.2)\end{array}$ \\
\hline $77: 12$ & $\begin{array}{l}2.225 \\
(11.6)\end{array}$ & $\begin{array}{l}0.703 \\
(17.1)\end{array}$ & $\begin{array}{l}-0.881 \\
(-11.3)\end{array}$ & $\begin{array}{l}-0.163 \\
(-0.2)\end{array}$ & $\begin{array}{l}0.200 \\
(0.2)\end{array}$ \\
\hline $78: 12$ & $\begin{array}{l}2.200 \\
(11.8)\end{array}$ & $\begin{array}{l}0.718 \\
(18.3)\end{array}$ & $\begin{array}{l}-0.879 \\
(-11.6)\end{array}$ & $\begin{array}{l}-0.169 \\
(-0.3)\end{array}$ & $\begin{array}{l}2.687 \\
(1.7)\end{array}$ \\
\hline $79: 12$ & $\begin{array}{l}2.122 \\
(11.5)\end{array}$ & $\begin{array}{l}0.745 \\
(19.7)\end{array}$ & $\begin{array}{l}-0.895 \\
(-11.9)\end{array}$ & $\begin{array}{l}0.108 \\
(0.2)\end{array}$ & $\begin{array}{l}1.561 \\
(4.9)\end{array}$ \\
\hline $80: 12$ & $\begin{array}{l}1.766 \\
(9.0)\end{array}$ & $\begin{array}{l}0.843 \\
(22.9)\end{array}$ & $\begin{array}{l}-0.960 \\
(-11.7)\end{array}$ & $\begin{array}{l}0.933 \\
(2.9)\end{array}$ & $\begin{array}{l}2.897 \\
(5.9)\end{array}$ \\
\hline $81: 12$ & $\begin{array}{l}1.537 \\
(6.5)\end{array}$ & $\begin{array}{l}0.929 \\
(21.3)\end{array}$ & $\begin{array}{l}-0.880 \\
(-8.8)\end{array}$ & $\begin{array}{l}1.076 \\
(3.2)\end{array}$ & $\begin{array}{l}4.277 \\
(8.5)\end{array}$ \\
\hline $82: 12$ & $\begin{array}{l}1.709 \\
(6.6)\end{array}$ & $\begin{array}{l}0.923 \\
(19.4)\end{array}$ & $\begin{array}{l}-0.611 \\
(-6.1)\end{array}$ & $\begin{array}{l}1.780 \\
(5.4)\end{array}$ & $\begin{array}{l}-5.649 \\
(-7.3)\end{array}$ \\
\hline $83: 12$ & $\begin{array}{l}2.203 \\
(7.7)\end{array}$ & $\begin{array}{l}0.922 \\
(17.5)\end{array}$ & $\begin{array}{l}-0.020 \\
(-0.2)\end{array}$ & $\begin{array}{l}0.468 \\
(1.4)\end{array}$ & $\begin{array}{l}1.250 \\
(0.3)\end{array}$ \\
\hline $84: 12$ & $\begin{array}{l}2.251 \\
(8.0)\end{array}$ & $\begin{array}{l}0.918 \\
(17.7)\end{array}$ & $\begin{array}{l}0.002 \\
(0.0)\end{array}$ & $\begin{array}{l}0.465 \\
(1.4)\end{array}$ & $\begin{array}{l}-9.381 \\
(-4.3)\end{array}$ \\
\hline $85: 12$ & $\begin{array}{l}2.353 \\
(8.3)\end{array}$ & $\begin{array}{l}0.923 \\
(17.6)\end{array}$ & $\begin{array}{l}0.052 \\
(0.6)\end{array}$ & $\begin{array}{l}0.214 \\
(0.7)\end{array}$ & $\begin{array}{l}1.168 \\
(2.3)\end{array}$ \\
\hline $86: 12$ & $\begin{array}{l}2.498 \\
(9.2)\end{array}$ & $\begin{array}{l}0.899 \\
(17.9)\end{array}$ & $\begin{array}{l}0.087 \\
(1.0)\end{array}$ & $\begin{array}{l}0.476 \\
(1.7)\end{array}$ & $\begin{array}{l}-0.030 \\
(-0.0)\end{array}$ \\
\hline $87: 12$ & $\begin{array}{l}2.488 \\
(9.5)\end{array}$ & $\begin{array}{l}0.902 \\
(18.5)\end{array}$ & $\begin{array}{l}0.084 \\
(0.9)\end{array}$ & $\begin{array}{l}0.420 \\
(1.7)\end{array}$ & $\begin{array}{r}-0.337 \\
(-0.7)\end{array}$ \\
\hline
\end{tabular}


TABLE $\underline{3}$ (Continued)

$\begin{array}{llllll}88: 12 & 2.557 & 0.909 & 0.066 & 0.228 & -0.565 \\ & (9.9) & (18.9) & (0.8) & (1.1) & (-0.3) \\ 89: 12 & 2.577 & 0.910 & 0.057 & 0.209 & -2.849 \\ & (10.1) & (19.2) & (0.7) & (1.0) & (-3.5) \\ 90: 12 & 2.647 & 0.923 & 0.011 & -0.001 & 0.223 \\ & (10.4) & (19.4) & (0.1) & (-0.0) & (0.1) \\ 91: 12 & 2.631 & 0.922 & 0.008 & 0.007 & 1.470 \\ & (10.5) & (19.7) & (1.0) & (0.0) & (1.8) \\ 92: 12 & 2.566 & 0.926 & -0.013 & 0.091 & 1.380 \\ & (10.4) & (19.9) & (-0.2) & (0.5) & (3.0) \\ 93: 12 & 2.499 & 0.930 & -0.046 & 0.286 & 1.721 \\ & (10.2) & (20.1) & (-0.6) & (1.6) & (3.5) \\ 94: 12 & 2.383 & 0.941 & -0.069 & 0.433 & 0.247 \\ & (9.9) & (20.5) & (-0.8) & (2.6) & (0.4)\end{array}$

Notes: Numbers in parentheses are t-statistics.

Gap between actual and target $M 2$ is measured from the mid-point of the designated target range. 
TABLE 4

MONETARY POLICY REACTION FUNCTIONS ALLOWING FOR M2 GROWTH TARGETS (DISTINGUISHING MONEY IN OR OUT OF TARGET RANGE)

\begin{tabular}{|c|c|c|c|c|c|c|}
\hline End of Sample & $\alpha$ & $\mathrm{B} \pi$ & $x\left(U-U^{*}\right)$ & $\underline{\theta(1-D)\left(m-m^{T}\right)}$ & $\underline{\delta \cdot D\left(m-m^{T}\right)}$ & $\begin{array}{c}\text { Months Out } \\
\text { of Range }\end{array}$ \\
\hline $75: 4$ & $\begin{array}{l}2.201 \\
(10.7)\end{array}$ & $\begin{array}{l}0.712 \\
(14.7)\end{array}$ & $\begin{array}{l}-0.866 \\
(-8.3)\end{array}$ & $\begin{array}{l}-- \\
\cdots\end{array}$ & $\begin{array}{l}- \\
-\end{array}$ & $\begin{array}{l}-. \\
-\end{array}$ \\
\hline $75: 12$ & $\begin{array}{l}2.226 \\
(11.0)\end{array}$ & $\begin{array}{l}0.702 \\
(15.9)\end{array}$ & $\begin{array}{l}-0.880 \\
(-10.0)\end{array}$ & $\begin{array}{l}-- \\
-\end{array}$ & $\begin{array}{l}-0.272 \\
(-0.1)\end{array}$ & $\begin{array}{l}8 \\
--\end{array}$ \\
\hline $76: 12$ & $\begin{array}{l}2.226 \\
(11.3)\end{array}$ & $\begin{array}{l}0.701 \\
(16.6)\end{array}$ & $\begin{array}{l}-0.881 \\
(-10.9)\end{array}$ & $\begin{array}{l}-0.267 \\
(-0.1)\end{array}$ & $\begin{array}{c}-0.202 \\
(-0.1)\end{array}$ & $\begin{array}{l}9 \\
--\end{array}$ \\
\hline $77: 12$ & $\begin{array}{l}2.226 \\
(11.6)\end{array}$ & $\begin{array}{l}0.704 \\
(17.2)\end{array}$ & $\begin{array}{l}-0.879 \\
(-11.4)\end{array}$ & $\begin{array}{l}-0.256 \\
(-0.2)\end{array}$ & $\begin{array}{c}-0.019 \\
(-0.0)\end{array}$ & $\begin{array}{l}8 \\
--\end{array}$ \\
\hline $78: 12$ & $\begin{array}{l}2.188 \\
(11.7)\end{array}$ & $\begin{array}{l}0.724 \\
(18.6)\end{array}$ & $\begin{array}{l}-0.879 \\
(-11.7)\end{array}$ & $\begin{array}{c}-0.401 \\
(-0.4)\end{array}$ & $\begin{array}{l}3.883 \\
(1.2)\end{array}$ & $\begin{array}{l}8 \\
\cdots\end{array}$ \\
\hline $79: 12$ & $\begin{array}{l}2.084 \\
(11.2)\end{array}$ & $\begin{array}{l}0.759 \\
(20.2)\end{array}$ & $\begin{array}{l}-0.896 \\
(-11.9)\end{array}$ & $\begin{array}{l}-0.176 \\
(-0.2)\end{array}$ & $\begin{array}{l}3.327 \\
(4.3)\end{array}$ & 10 \\
\hline $80: 12$ & $\begin{array}{l}1.714 \\
(8.7)\end{array}$ & $\begin{array}{l}0.863 \\
(23.6)\end{array}$ & $\begin{array}{l}-0.959 \\
(-11.5)\end{array}$ & $\begin{array}{l}1.449 \\
(2.1)\end{array}$ & $\begin{array}{r}12.918 \\
(5.5)\end{array}$ & $\begin{array}{l}6 \\
-\end{array}$ \\
\hline $81: 12$ & $\begin{array}{l}1.446 \\
(6.0)\end{array}$ & $\begin{array}{l}0.965 \\
(22.4)\end{array}$ & $\begin{array}{l}-0.861 \\
(-8.6)\end{array}$ & $\begin{array}{l}1.283 \\
(1.5)\end{array}$ & $\begin{array}{r}12.638 \\
(8.3)\end{array}$ & 11 \\
\hline $82: 12$ & $\begin{array}{l}1.662 \\
(6.2)\end{array}$ & $\begin{array}{l}0.965 \\
(19.8)\end{array}$ & $\begin{array}{c}-0.501 \\
(-4.9)\end{array}$ & $\begin{array}{l}2.928 \\
(3.4)\end{array}$ & $\begin{array}{c}-8.682 \\
(-5.8)\end{array}$ & $\begin{array}{l}8 \\
--\end{array}$ \\
\hline $83: 12$ & $\begin{array}{l}2.093 \\
(7.4)\end{array}$ & $\begin{array}{l}0.954 \\
(18.6)\end{array}$ & $\begin{array}{l}-0.056 \\
(-0.4)\end{array}$ & $\begin{array}{c}-0.100 \\
(-0.1)\end{array}$ & $\begin{array}{r}446.931 \\
(1.5)\end{array}$ & $\begin{array}{l}1 \\
--\end{array}$ \\
\hline $84: 12$ & $\begin{array}{l}2.294 \\
(8.0)\end{array}$ & $\begin{array}{l}0.938 \\
(18.1)\end{array}$ & $\begin{array}{l}0.035 \\
(0.4)\end{array}$ & $\begin{array}{c}-0.159 \\
(-0.2)\end{array}$ & $\begin{array}{r}-65.222 \\
(-1.0)\end{array}$ & $\begin{array}{l}1 \\
\cdots\end{array}$ \\
\hline $85: 12$ & $\begin{array}{l}2.330 \\
(8.3)\end{array}$ & $\begin{array}{l}0.935 \\
(18.3)\end{array}$ & $\begin{array}{l}0.047 \\
(0.5)\end{array}$ & $\begin{array}{l}-0.177 \\
(-0.2)\end{array}$ & $\begin{array}{l}2.053 \\
(2.0)\end{array}$ & $\begin{array}{l}12 \\
\ldots\end{array}$ \\
\hline $86: 12$ & $\begin{array}{l}2.464 \\
(9.2)\end{array}$ & $\begin{array}{l}0.913 \\
(18.6)\end{array}$ & $\begin{array}{l}0.081 \\
(0.9)\end{array}$ & $\begin{array}{l}0.605 \\
(1.0)\end{array}$ & $\begin{array}{l}-1.859 \\
(-0.4)\end{array}$ & $\begin{array}{l}7 \\
-\end{array}$ \\
\hline
\end{tabular}


TABLE $\underline{4}$ (Continued)

\begin{tabular}{|c|c|c|c|c|c|c|}
\hline $87: 12$ & $\begin{array}{l}2.468 \\
(9.4)\end{array}$ & $\begin{array}{l}0.913 \\
(18.9)\end{array}$ & $\begin{array}{l}0.081 \\
(0.9)\end{array}$ & $\begin{array}{l}0.605 \\
(1.0)\end{array}$ & $\begin{array}{c}-0.705 \\
(-0.7)\end{array}$ & 11 \\
\hline $88: 12$ & $\begin{array}{l}2.535 \\
(9.8)\end{array}$ & $\begin{array}{l}0.916 \\
(19.2)\end{array}$ & $\begin{array}{l}0.065 \\
(0.7)\end{array}$ & $\begin{array}{l}0.245 \\
(0.5)\end{array}$ & $\begin{array}{r}-2.130 \\
(-0.2)\end{array}$ & $\begin{array}{l}1 \\
-.\end{array}$ \\
\hline $89: 12$ & $\begin{array}{l}2.591 \\
(10.2)\end{array}$ & $\begin{array}{l}0.917 \\
(19.4)\end{array}$ & $\begin{array}{l}0.042 \\
(0.5)\end{array}$ & $\begin{array}{l}0.218 \\
(0.4)\end{array}$ & $\begin{array}{r}-8.250 \\
(-2.6)\end{array}$ & $\begin{array}{l}5 \\
\cdots\end{array}$ \\
\hline $90: 12$ & $\begin{array}{l}2.641 \\
(10.4)\end{array}$ & $\begin{array}{l}0.923 \\
(19.6)\end{array}$ & $\begin{array}{l}0.013 \\
(0.1)\end{array}$ & $\begin{array}{c}-0.021 \\
(-0.0)\end{array}$ & $\begin{array}{r}23.618 \\
(0.7)\end{array}$ & $\begin{array}{l}1 \\
\cdots\end{array}$ \\
\hline $91: 12$ & $\begin{array}{l}2.595 \\
(10.4)\end{array}$ & $\begin{array}{l}0.925 \\
(19.8)\end{array}$ & $\begin{array}{l}0.001 \\
(0.0)\end{array}$ & $\begin{array}{l}0.004 \\
(0.0)\end{array}$ & $\begin{array}{l}6.880 \\
(0.2)\end{array}$ & $\begin{array}{l}1 \\
-.\end{array}$ \\
\hline $92: 12$ & $\begin{array}{l}2.533 \\
(10.3)\end{array}$ & $\begin{array}{l}0.932 \\
(20.2)\end{array}$ & $\begin{array}{c}-0.018 \\
(-0.2)\end{array}$ & $\begin{array}{l}0.014 \\
(0.0)\end{array}$ & $\begin{array}{l}5.275 \\
(2.8)\end{array}$ & $\begin{array}{l}7 \\
-.\end{array}$ \\
\hline $93: 12$ & $\begin{array}{l}2.388 \\
(9.8)\end{array}$ & $\begin{array}{l}0.948 \\
(20.6)\end{array}$ & $\begin{array}{c}-0.059 \\
(-0.7)\end{array}$ & $\begin{array}{l}0.345 \\
(0.7)\end{array}$ & $\begin{array}{l}3.366 \\
(2.7)\end{array}$ & $\begin{array}{l}8 \\
--\end{array}$ \\
\hline $94: 12$ & $\begin{array}{l}2.284 \\
(9.6)\end{array}$ & $\begin{array}{l}0.958 \\
(21.1)\end{array}$ & $\begin{array}{l}-0.078 \\
(-0.9)\end{array}$ & $\begin{array}{l}0.716 \\
(1.6)\end{array}$ & $\begin{array}{r}-51.456 \\
(-0.2)\end{array}$ & 1 \\
\hline
\end{tabular}

Notes: Numbers in parentheses are t-statistics.

Gap between actual and target $M 2$ is measured from the near boundary of the designated target range. 
money growth makes little difference. The results again show evidence that the Federal Reserve actively targeted M2 growth during 1978-1981, in 1985, and during 1992-1993. 
IV. Did the Rise and Fall of Money Growth Targets Make Sense?

How, then, do the changes in the use of money growth targets documented in Tables $1-4$ correspond to the changing relationships between money and output and between money and prices traced out in Figures 1-8? Were these shifts sensible responses to changing economic circumstances?

To be sure, nobody believes that monetary policymakers were necessarily monitoring the evolving results of exercises like those reported in Figures 1-8 on a continuous basis from 1975 onward. (Indeed, the vector autoregression methodology only came into familiar use in economics in the late 1970s and thereafter.) But empirical relationships that address the key questions at issue here, in one way or another, were central to how policymakers and others in fact conceived the role of monetary aggregates in the monetary policy process. Whether money does or does not have predictive content with respect to output and/or prices is essential to whether the use of money growth targets constitutes a potentially effective strategy under which to carry out monetary policy. Policymakers need not have been tracking estimated relationships of the exact form as those reported here. But to the extent that these relationships, based on data only up through specific points in time, provide an indication of whether there was or was not evidence then that money had such predictive content, that kind of evidence, or the lack of it, at least should have been an important factor in the choice of monetary policy strategy.

Resolution 133 . The empirical case for money growth targets was weak at best when Congress adopted Resolution 133 in early 1975. Evidence based on data through yearend 1974 indicated that Ml accounted for only a small percentage of the subsequent variation of either output or prices, and after allowance for the effect of interest rates these affects were statistically significant either marginally or not at all. M2 did appear to account for a large and significant 
share of the subsequent variation of output -- though not prices - - but this apparent relationship became much smaller and lost its statistical significance after allowance for interest rates.

The Federal Reserve System, however, appears to have acted consistently with this state of affairs. Although the Federal Reserve of course met its new statutory obligation to announce money growth targets, the results presented in Tables 1-4 provide no evidence that these targets actually influenced monetary policy actions in the near-term aftermath of the resolution's adoption. Both Ml and M2 were outside the designated target range most of the time in the latter half of the 1970s, and there is no significant evidence of a response to this situation before 1978. Even for 1978 the estimated response is only marginally significant.

Volcker Monetarism. Monetary policy looks different beginning in 1979. For 1979-1981 there is strong evidence of an effort by the Federal Reserve to target both M1 and M2. Efforts to target M1 growth continued on through 1985 (although the evidence is strong only through 1984). During 1982-1984 the Federal Reserve mostly accommodated M2 demand, but there is renewed evidence of an effort to target M2 growth in 1985.

Especially with respect to $M 1$ in 1979 and the first few years thereafter, this change in policy appears in retrospect to have been consistent with changing evidence on key economic relationships. Indeed, from the evidence presented in Figure 3 it appears that the Federal Reserve might well have begun earlier to target M1 growth. In the late 1970s evidence was becoming stronger that MI did account for a sizeable and statistically significant percentage of the subsequent variation of prices (though not output), especially after allowance for interest rates. Given the concern at time for the upward spiral of inflation, targeting M1 beginning in 1979 seems to have been appropriate, if 
not late. By contrast, the evidence on $M 2$ is much weaker. M2 did appear to explain a large percentage of the subsequent variations of output (though not prices), but this effect became statistically significant only after 1979. Moreover, the predictive content of M2 measured directly from the autoregression was completely insignificant once interest rates were taken into account.

The main contradiction between policy actions and the underlying economic relationships during this period, however, lies in the Federal Reserve's continuing attempts to target $\mathrm{Ml}$ after $1982 .{ }^{15}$ with or without interest rates taken into account, the relationship between $M 1$ and prices rapidly lost significance as seen from vantage points beginning in early 1983. To recall, these were years of rapid money growth $(8.88$ in $1982,10.48$ in $1983,12.08$ in 1985, 15.58 in 1986), which - - contrary to the public warnings of many advocates of monetary targeting -- did not result in a renewed increase of inflation rates. Although the fact that money growth was so rapid immediately reveals that the Federal Reserve was not totally committed to its growth targets, the results in Tables 1 and 2 provide evidence that M1 growth remained an independent influence on Federal Reserve policy actions during these years.

M2 Under Greenspan. After 1986 the Federal Reserve stopped even setting growth targets for $M 1$, and there is no evidence of renewed attention to M2 targets until the early 1990s. Ignoring Ml growth was entirely consistent with the relationships - - more accurately, the absence of relationships -- that were evident between M1 and output and prices. Since 1987 there has been no evidence of a significant relationship between $M 1$ and either output or prices, either with or without allowance for interest rates. The picture is more mixed for M2, however, especially after taking interest rates into account. The percentage of the subsequent variation of output attributable to $M 2$ was declining in these years, but it remained significant until 1989. By contrast, the predictive 
content measured directly from the regression was not significant as judged from these vantage points.

In 1992 and 1993, however, the Federal Reserve returned to actively targeting M2 growth. (As Table 3 shows, there is marginally significant evidence for active M2 targeting in 1991 as well.) Judging on the basis of the relationship between $M 2$ and real output shown in Figures $5-8$, it is perhaps possible to justify this renewed emphasis on $M 2$ as a response to changing economic conditions. The deterioration in the percentage of output variation attributable to $M 2$ reversed itself for vantage points beginning in 1990 , and by 1992 this effect was again statistically significant with interest rates taken into account (see Figure 7). Even at the peak in 1993, however, it was never very large. Similarly, what had been a deterioration in the statistical significance of the predictive content of M2 with respect to real output measured directly from the regression also reversed itself in 1990, but with interest rates taken into account the effect remained insignificant (see Figure 8). On balance, it is difficult to justify the return to $M 2$ targeting by an analysis that also allows for the effect of interest rates.

Downgrading. In 1993 the Federal Reserve publicly announced that it had "downgraded" even its M2 target, and Table 3 confirms that there is no evidence of an active attempt to target $M 2$ growth in 1994 . (M2 was within the target range virtually throughout 1994, but there is no evidence of any influence of M2 on the federal funds rate independent of the influence of inflation and unemployment.) This "downgrading" appears entirely warranted. M2 had never shown any relationship to prices anyway, and what evidence there was of a relationship to output weakened noticeably beginning in 1993 and then disappeared by the end of 1994 . 


\section{Concluding observations}

For the most part, therefore, the Federal Reserve System's use and disuse of money growth targets as guidelines for U.S. monetary policy over the past twenty years appears to have been roughly consistent with what the evidence of the time on money-output and money-price relationships has warranted. With some notable exceptions, money growth targets have been a visible influence on monetary policy actions primarily at times when at least some forms of evidence on these relationships appeared to justify it. More obviously, the Federal Reserve's stepping back from money growth targets has been entirely consistent with what the economic evidence has warranted.

In assessing these conclusions, it is useful to keep in mind that the evidence on the key money-output and money-price relationships on which they rely follows from an application (actually, 101 successive applications) of the standard methodology based on vector autoregressions and the associated variance decompositions. More flexible empirical strategies - - in particular, methods incorporating error-correction mechanisms -- could lead to stronger evidence of a relationship between money and either output or prices, and hence might support a different assessment of what the Federal Reserve has done over these two decades. 16

But incorporating an error-correction mechansism in the analysis would importantly change the implication for monetary policy of whatever money-output or money-price relationships might emerge. To recall, the distinction between using money growth as an intermediate target and using money growth as an information variable hinges on whether or not the central bank consistently acts as if observed deviations of money from the designated growth path constitute signs of undesired movements to come in output and/or prices (or whatever else monetary policy is ultimately seeking to influence). By contrast, the use of an 
error-correction mechanism rests on the explicit assumption that the underlying relationships do not support such an interpretation. Observed deviations of money growth then do not just represent disburbances to output and/or prices, but also systematically reflect aberrant money demand or money supply behavior. Depending on the circumstances accounting for that aberrant behavior, money growth could still be a useful tool for monetary policy in the form of an information variable. But evidence of this form would not support the use of money growth as a target for monetary policy.

And so money growth targets arrived and, not long after, disappeared. The British historian R. H. Tawney presumably did not have late twentieth century U.S. monetary policy in mind when he offered this judgment nearly three-quarters of a century ago, but his conclusion aptly summarizes the recent experience with money growth targets nonetheless: "Their practical ineffectiveness prepared the way for their theoretical abandonment. They were abandoned because, on the whole, they deserved to be abandoned." 17 
FIGURE A-1

BBRGENTAGES OF OUTPUT AND PRICE YARTATION ACCOUNTED FOR BY MI AT A ONF-YTAR HORIZON DOR 101 SAYPILSS

Real GDP

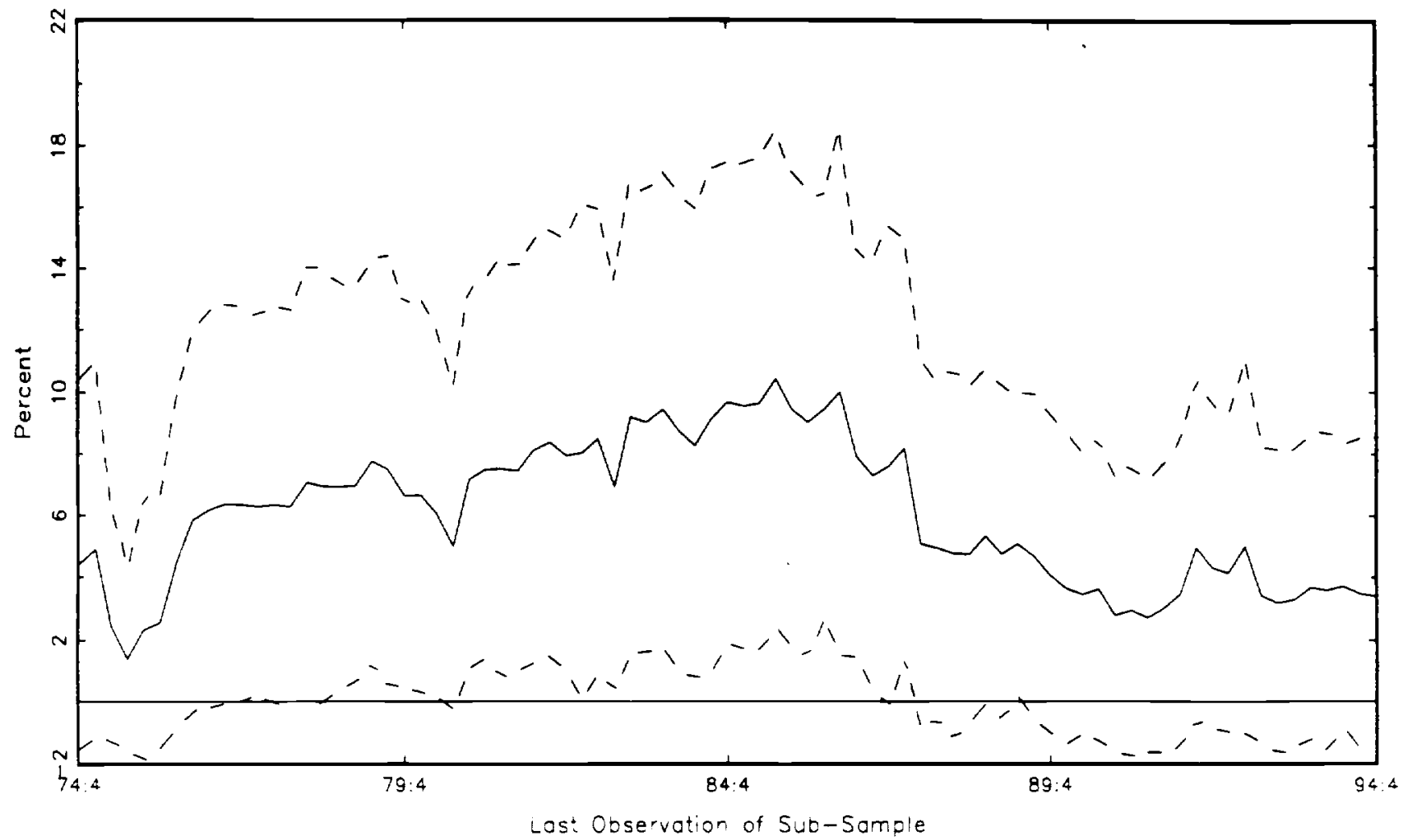

GDF Deflotor

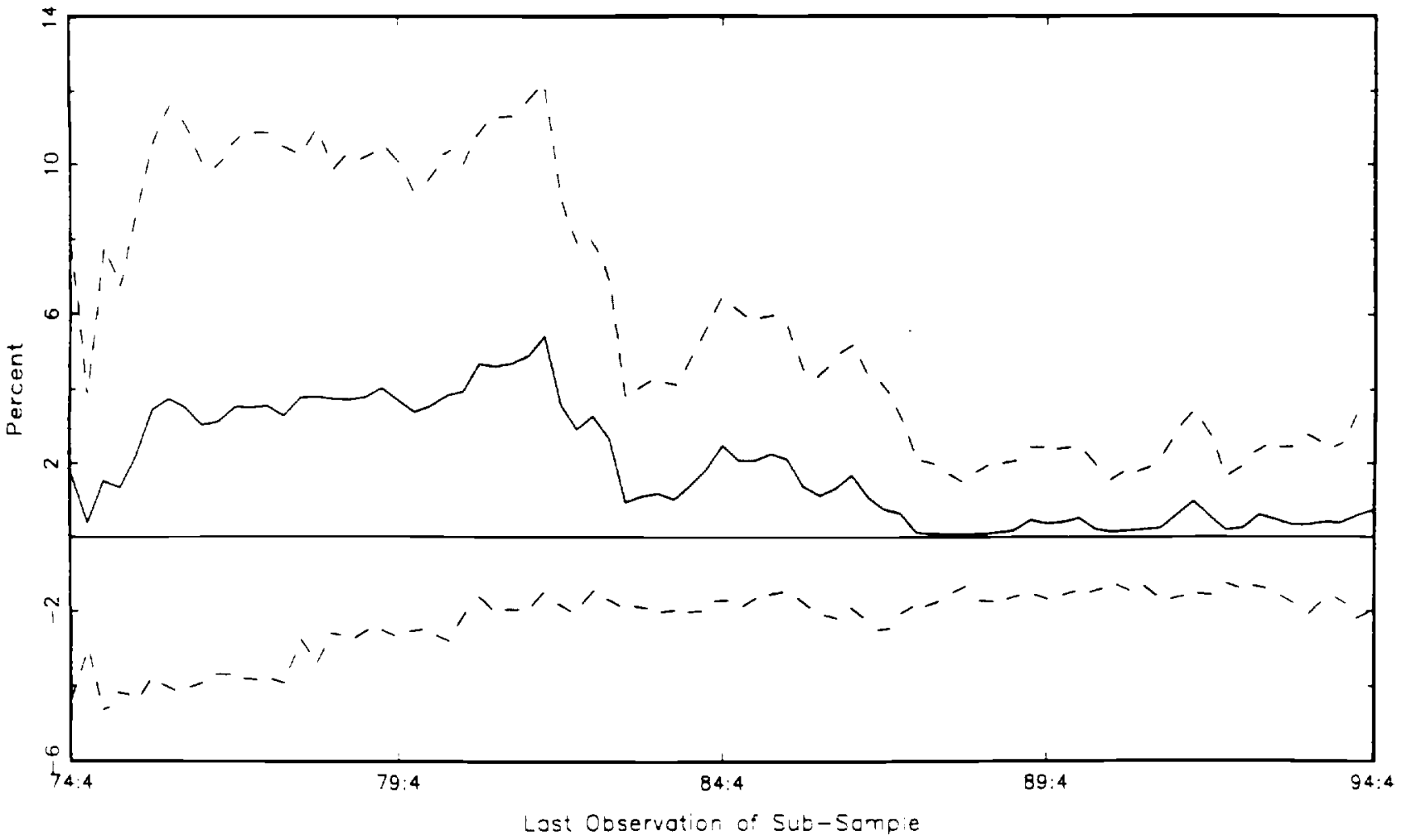




\section{FIGURE A-2}

PERCBNTAGES OF OUTPUT AND PRICE YARIATION ACCOLNTED FOR BY MI AT A ONE-YTAB HORIZON EOR 101 SAMPILSS (SYSTBY ALSO IKCLUDES EEDERAL EUNDS RATE)

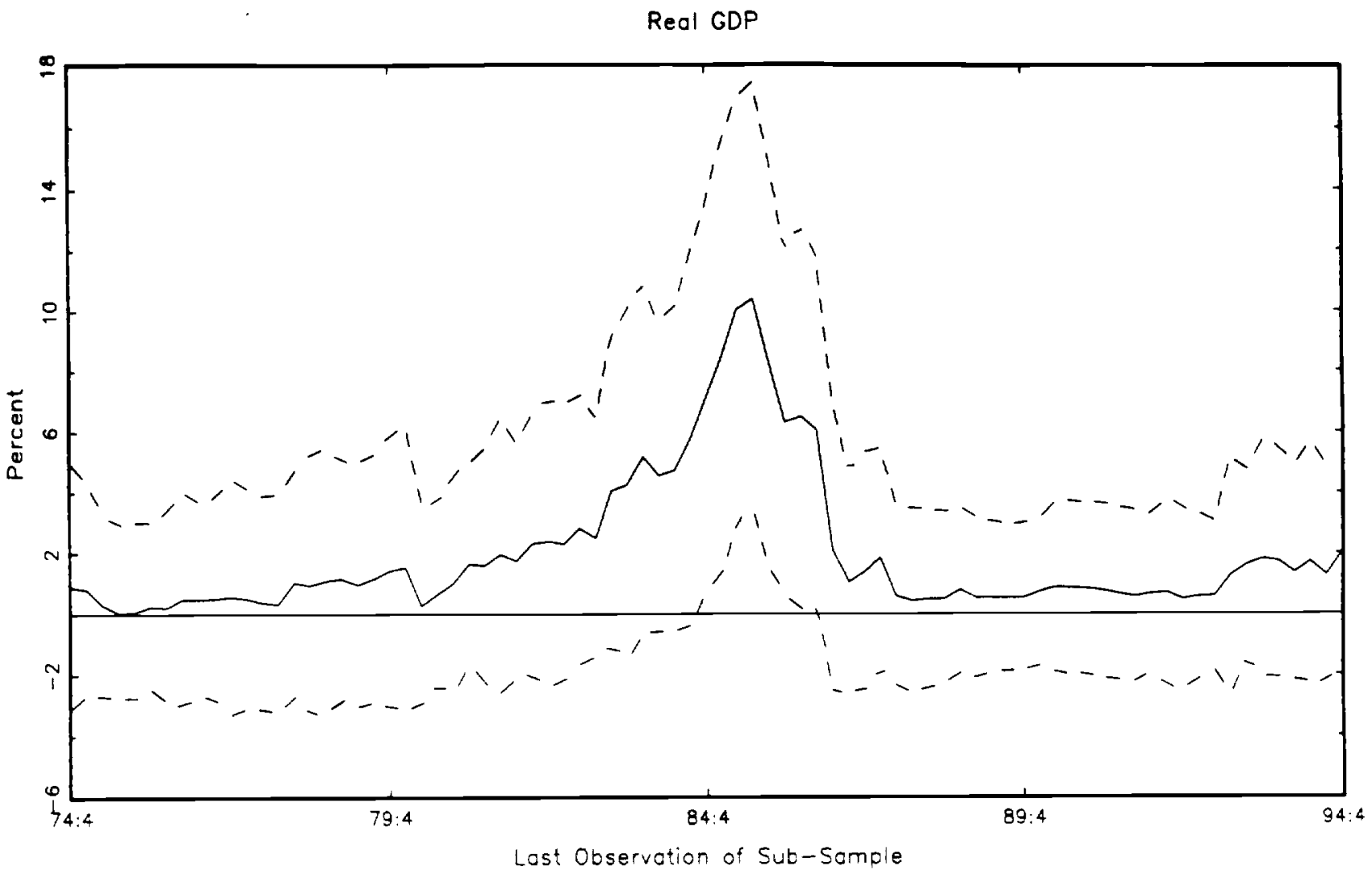

GDP Deflator

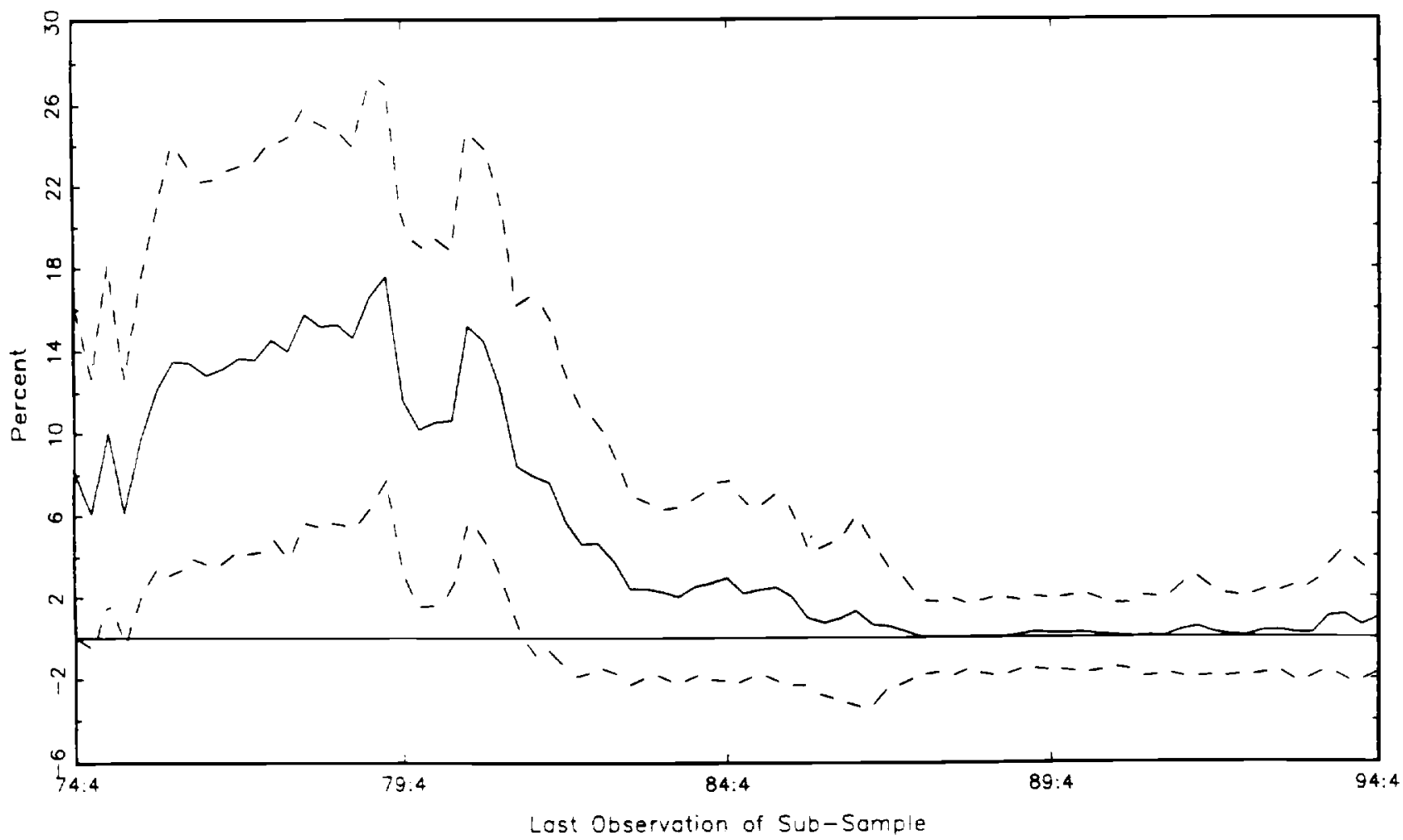


FIGURE -3

PERCENTAGES OF OUTPUT AND RRICE VARIATION ACCOUNTED EOR BY 12 AT $\triangle$ OAR-YBAB HORIZON BOR 101 SAMPLES

Reol GDP

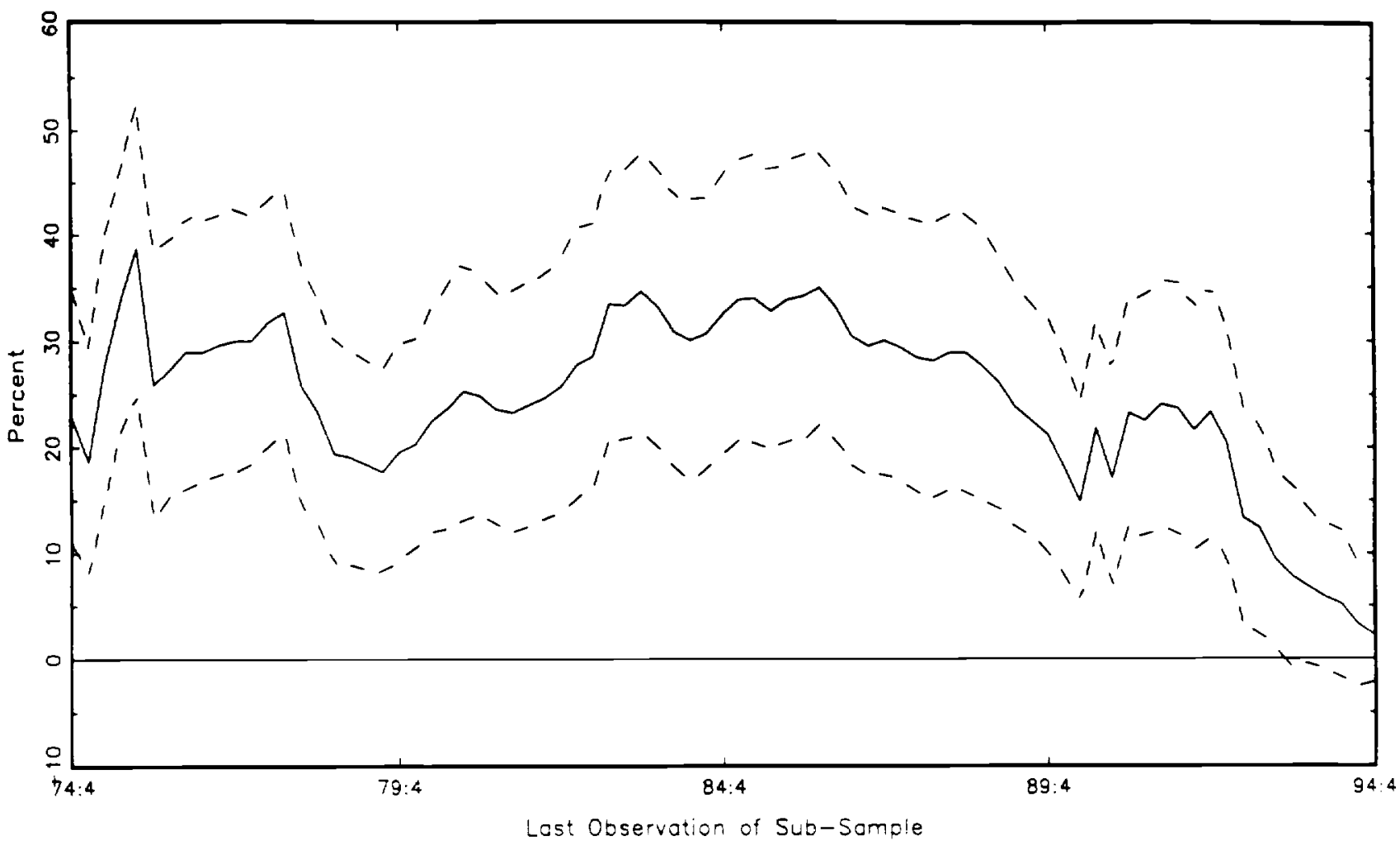

GDP Deflator

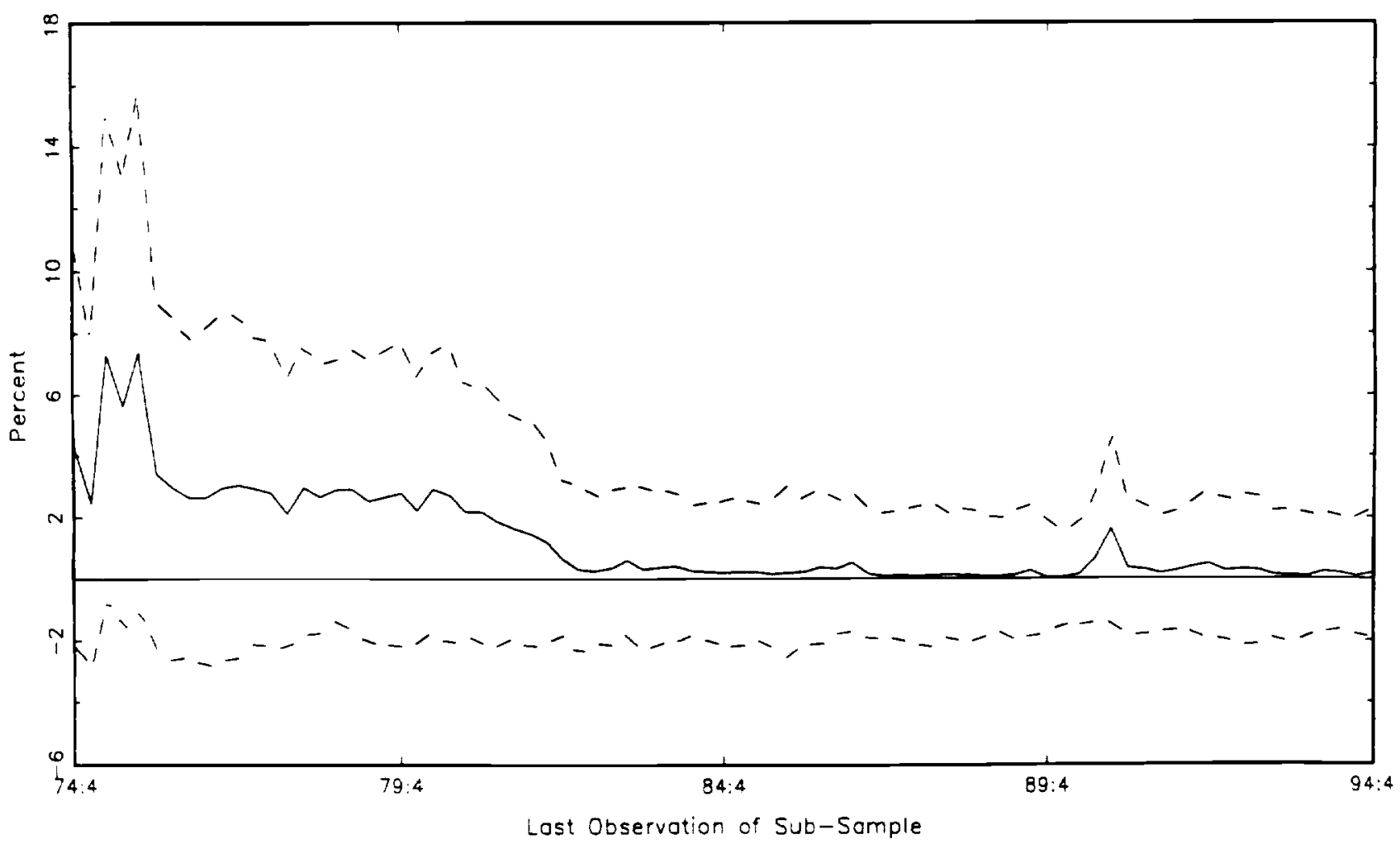


EIGURE A-4

PERCENTAGES OF OUTPUT AND PRICE VARIATION ACCOUNTED FOR BY 2 AT A ONE-YEAR HORIZON BOR 101 SAMPLES (SYSTBY AISO INCLIDES EEDERAL EUNDS RATE)

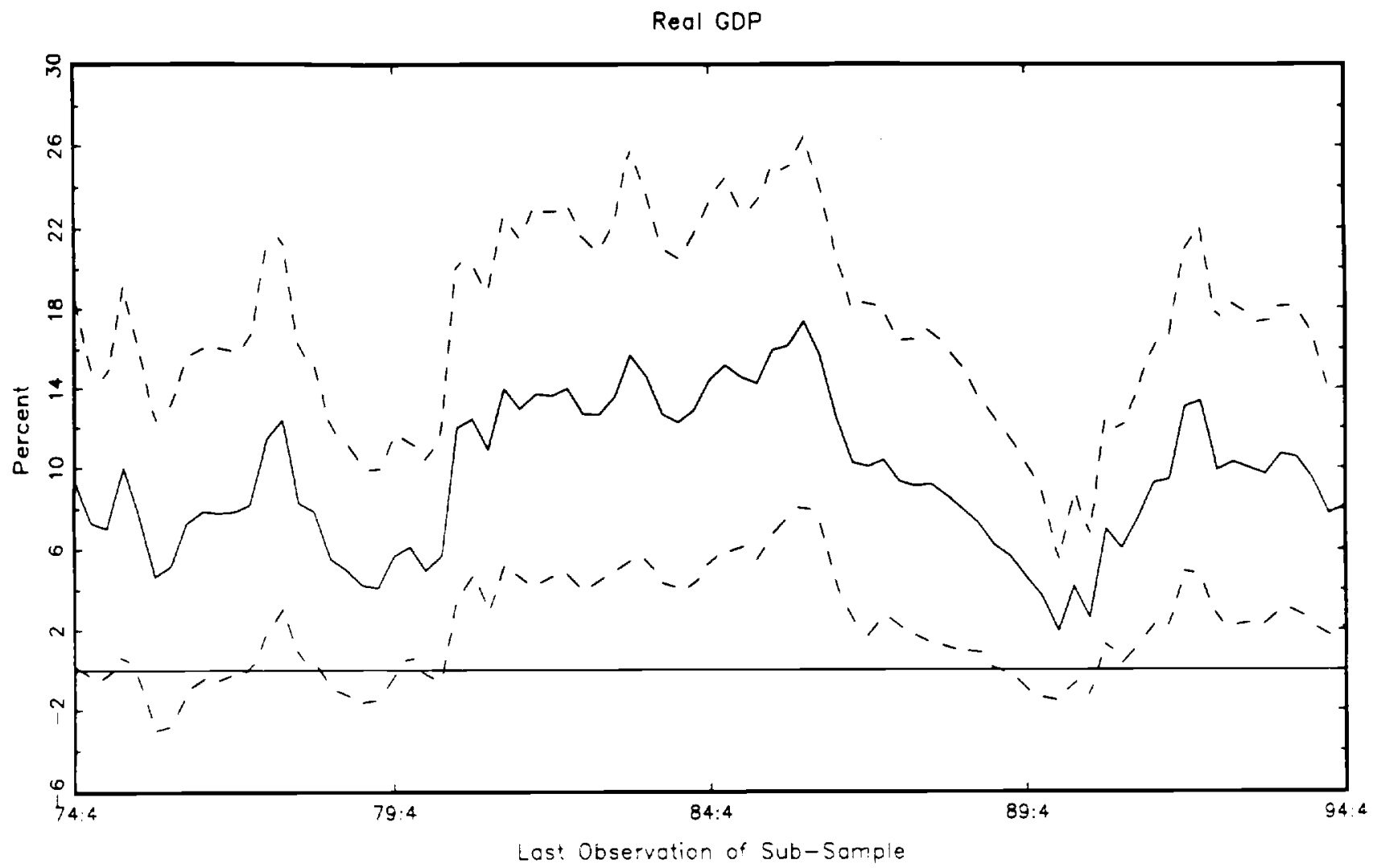

GOP Deflotor

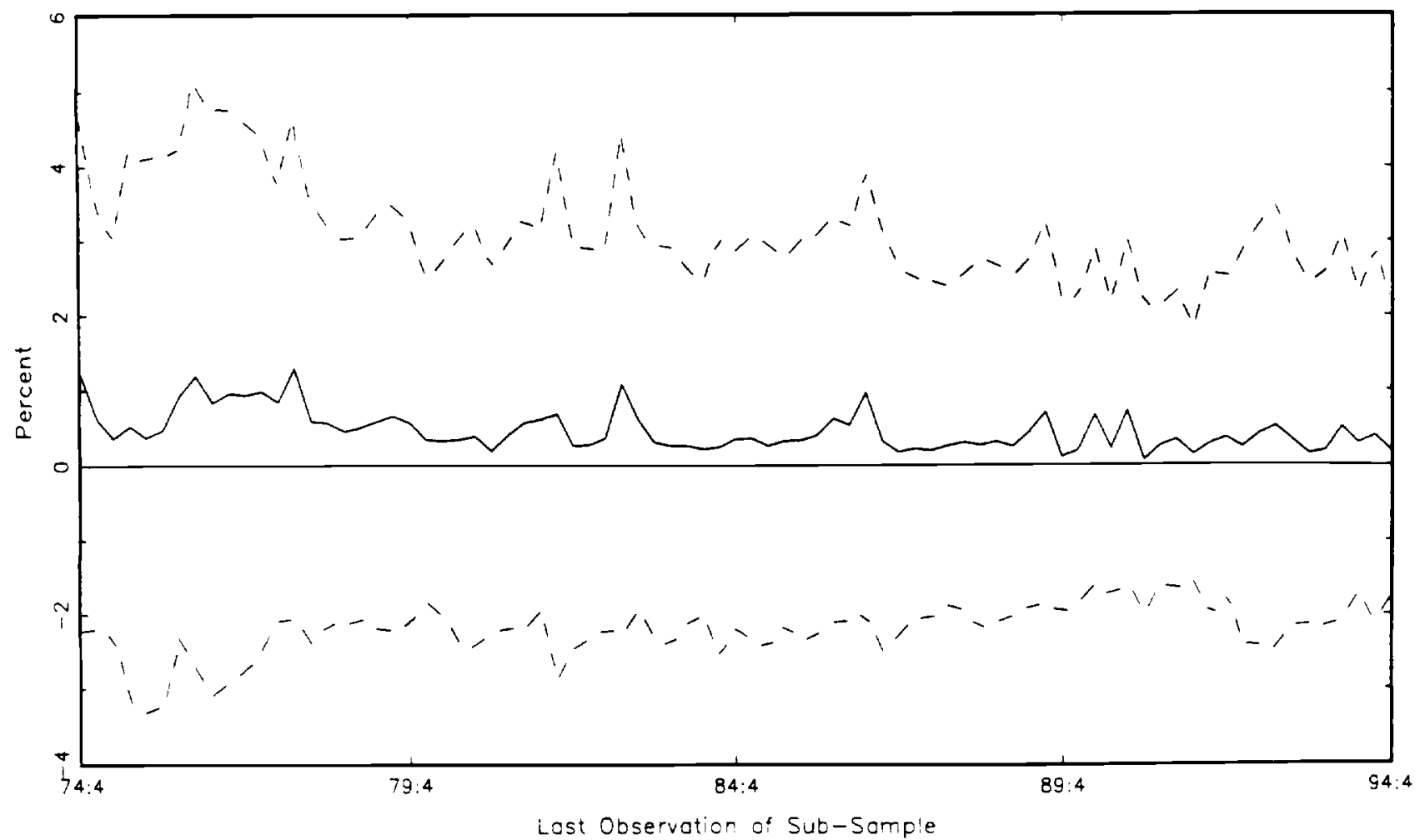




\section{Footnotes}

*This paper was prepared for the Bank of Japan conference "Toward A More Effective Monetary Policy," Tokyo, October 26-27, 1995. I am grateful to Jeff Amato for research assistance, to Stephen Cecchetti, Kenneth Kuttner, David Longworth, Gregory Mankiw, William Poole, Jordan Rappaport, George Rich and James Stock for helpful discussions and comments on an earlier draft, to Donald Kohn and Richard Porter for their cooperation in providing data, and to the G. E. Foundation and the Harvard Program for Financial Research for research support.

1. This section draws on my previous work, including in particular Friedman (1990, 1993).

2. See the evidence provided by DeRosa and Stern (1977).

3. To show more precisely how someone in early 1975 would have answered this question would require using the data (for each of GDP, the deflator and M1) that existed then - - not, as here, the revised data for 1959-74 that exist now. The work reported in Section III below follows that approach. In this section the emphasis is instead on how the relevant economic behavior has changed over time.

4. See the discussion in Sims et al. (1990).

5. Stock and Watson (1989) among others, argued that also including a time trend in the regression restored the predictive content of $M 1$ with respect to output even in the presence of an interest rate, but Friedman and Kuttner (1993) showed that this result depended on the use of a specific interest rate. In line with the discussion above, Stock and Watson's result also disappeared when their 1960-1985 sample was extended to 1990.

6. These results highlight the tension in the current literature between use of variance decompositions and use of Granger-Sims "causality" tests, and also between use of levels and use of differenced data. See again the discussion above in connection with Figures 1 and 2 .

7. A further possibility is that the underlying behavior did not actually change, but changes in the conduct of monetary policy -- in particular, prospective variation of money growth, to offset anticipated disturbances to output and/or prices -- caused regression-based methodologies to be unable to discern the continuing relationship between money and these variables (see, for example, Poole (1994) and Friedman (1995)). But the widespread evidence of changes in the public's behavior based on direct tests of money demand behavior strongly contradicts the possibility that this effect could be solely, or even largely, responsible for the changes in predictive content documented in Figures 1-8. Note also, for example, Cecchetti's (1995) evidence of changes in relationships between inflation and other traditional "inflation indicators."

8. The price index used is "core CPI-U" - . that is, the consumer price index for all urban consumers, excluding food and energy items. The inflation 
rate is calculated as $\pi_{t-1}=P_{t-1}-P_{t-13}$ where $P$ is the logarithm of the price index. The unemployment rate is the rate for the civilian labor force aged sixteen and over. The natural rate is from Gordon (1993), Table A-2, rendered into monthly values and continued at 6.08 after 1992 . (Gordon's series ends in 1992:II, but it is constant at 6.08 throughout 1980-1992.)

9. The estimates are, of course, also consistent with other interpretations of interest rate behavior. The discussion below takes up the question of whether an equation analogous to (5) can be identified with monetary policy behavior.

10. The problem of within-year data revisions still remains. A more precise way to estimate (6) would be to use Federal Reserve data sources that were available on a month-by-month basis, but these data are not readily accessible.

11. An alternative procedure would be simply to allow $\delta$ in (6) to vary over time according to some standard time-varying parameter specification. Especially for the sample periods with later end dates, such a procedure would avoid the contradiction implicit in holding $\theta$ fixed over the entire period from 1975 through the penultimate year of the sample.

12. For 1980 and 1981 the Federal Reserve established separate targets for what were then called $\mathrm{Ml}-\mathrm{A}$ and $\mathrm{Ml}-\mathrm{B}$. For those two years the regression relies on the Ml-B aggregate, which as of 1982 was simply relabeled M1.

13. The reported t-statistics somewhat overstate the precision with which the regression measures $\delta$ (as well as the other coefficients) because of serial correlation in the errors. Serially correlated errors could easily result from the Federal Reserve's preference for interest rate smoothing, which the Taylor rule omits. With interest rate smoothing, the Federal Reserve's response to the included variables would assume a partial-adjustment form.

14. It would also be interesting to apply a time-varying parameter methodology to $\beta$ and $\gamma$ (see again footnote 11), but such an exercise lies beyond the scope of this paper. Fuhrer (1995) has attempted a form of that experiment, but in a different context and with unsatisfactory results. For purposes of questions like whether the response to inflation is sufficient to make the fluctuation of the real interest rate counterinstead of procyclical, it is important to remember that, with $\left(m-m^{T}\right)$ in the regression, what matters is not just $\beta$ but $\beta$ plus a term that depends on $\delta$.

15. It is worth pointing out that the finding here of active $M 1$ targeting after 1982 is contrary to the impression of many observers of U.S. monetary policy at the time.

16. For the use of error-correction methods in this context, see again Ramey (1992) and Feldstein and Stock (1994).

17. Tawney (1962), p. 185 . 


\section{References}

Cecchetti, S. G. (1995). Inflation Indicators and Inflation Policy. NBER Macroeconomics Annual.

DeRosa, P., and G. H. Stern (1977). Monetary Control and the Federal Funds Rate. Journal of Monetary Economics 3: 217-230.

Feinmann, J. N., and R. D. Porter (1992). The Continuing Weakness of M2. Mimeo: Federal Reserve Board.

Feldstein, M., and J. H. Stock (1994). The Use of A Monetary Aggregate to Target Nominal GDP. Mankiw (ed.), Monetary Policy. Chicago: University of Chicago Press.

Friedman, B. M. (1990). Targets and Instruments of Monetary Policy. Friedman and Hahn (eds.), Handbook of Monetary Economics, Vol.2. Amsterdam: Elsevier Science Publishers.

Friedman, B. M. (1993). The Role of Judgment and Discretion in the Conduct of Monetary Policy: Consequences of Changing Financial Markets. Changing Capital Markets: Implications for Monetary Policy. Kansas city: Federal Reserve Bank of Kansas City.

Friedman, B. M. (1996). Does Monetary Policy Affect Real Economic Activity? Why Do We Still Ask This Question? Siebert (ed.), Monetary Policy in an Integrated World Economy. Tubingen: J.C.B. Mohr, forthcoming.

Friedman, B. M., and K. N. Kuttner (1993). Another Look at the Evidence on Money-Income Causality. Journal of Econometrics 57: 189-203.

Friedman, M., and A. J. Schwartz (1963). A Monetary History of the United States 1867-1960. Princeton: Princeton University Press.

Fuhrer, J. C. (1995). Modeling Long-Term Nominal Interest Rates. Mimeo: Federal Reserve Bank of Boston.

Goldfeld, S. M. (1973). The Demand for Money Revisited. Brookings Papers on Monetary Policy: 577-638.

Gordon, R. J. (1993). Macroeconomics (6th ed.). New York: Harper Collins College Publishers.

Poole, W. (1994). Monetary Aggregates Targeting in a Low-Inflation Economy. Fuhrer (ed.), Goals, Guidelines, and Constraints Facing Monetary Policymakers. Boston: Federal Reserve Bank of Boston.

Ramey, V. (1993). How Important Is the Credit Channel in the Transmission of Monetary Policy? Mimeo: University of California, San Diego.

Sims, C. A. (1980). Comparison of Interwar and Postwar Business Cycles: Monetarism Reconsidered. American Economic Review 70: 250-257. 
Sims, C. A., J. H. Stock, and M. W. Watson (1990). Inference in Linear Time Series Models with Some Unit Roots. Econometrica 58: 113-144.

Stock, J. H., and M. W. Watson (1989). Interpreting the Evidence on Money-Income Causality. Journal of Econometrics 40: 161-182.

Tawney, R. H. (1962). Religion and the Rise of Capitalism. Gloucester, Mass. Peter Smith.

Taylor, J. B. (1993). Discretion Versus Policy Rules in Practice. CarnegieRochester Conference Series on Public Policy 39: 195-214. 